Original paper

\title{
Late Paleozoic and Early Mesozoic rare-metal granites in Central Mongolia and Baikal region: review of geochemistry, possible magma sources and related mineralization
}

\section{Viktor ANTIPIN ${ }^{1}$, Ochir GEREL2* ${ }^{*}$, Alexander PEREPELOV ${ }^{1}$, Dashdorjgochoo ODGEREL ${ }^{3}$, Tsegmed ZOLBOO ${ }^{1}$}

\author{
${ }^{1}$ Vinogradov Institute of Geochemistry, Favorsky 1a, Irkutsk, Russia \\ ${ }^{2}$ Mongolian University of Science and Technology, Baga Toiruu 34, Ulaanbaatar, Mongolia; gerel@must.edu.mn \\ ${ }^{3}$ Institute of Paleontology and Geology, Mongolian Academy of Sciences, Peace Avenue 62, Ulaanbaatar Mongolia \\ * Corresponding author
}

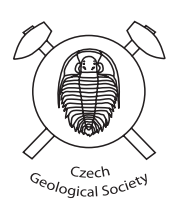

\begin{abstract}
The Central Asian Orogenic Belt (CAOB) was a scene of intense granitoid magmatism during the Phanerozoic with formation of vast batholiths: Angara-Vitim and Daurian-Khentei. In the Late Paleozoic and Early Mesozoic times, the peripheral zones of batholiths underwent granitic magmatism associated with rare-metal mineralization. Petrological and geochemical studies show that the rare-metal Li-F granites formed, with a gap about $100 \mathrm{My}$, large igneous provinces of the Mongol-Okhotsk Belt.

Late Paleozoic rare-metal granites build a series of multiphase plutons in the Baikal region (e.g. Kharagul $318 \pm 7 \mathrm{Ma}$, Bitu-Dzhida $311 \pm 10 \mathrm{Ma}$ and Urugudei $321 \pm 5 \mathrm{Ma}$ ). The early medium-grained biotite granites and leucogranites were followed by topaz-bearing microcline- and amazonite-albite granites and a series of dikes. The Early Mesozoic epoch was marked by the formation of the Daurian-Khentei Batholith (230-190 Ma) in the center of area and rifting zones with alkaline and rare-metal granite plutons on the peripheries. In contrast to the Late Paleozoic, small Early Mesozoic intrusions (e.g., Avdar Pluton $\sim 10 \mathrm{~km}^{2}$, 212-209 Ma) of rare-metal Li-F granites within the Avdar-Khoshutul series of granitoids coexisted with sizable plutons (e.g., Janchivlan Pluton $\sim 70 \mathrm{~km}^{2}, 227-195.3 \mathrm{Ma}$ ). Rare-metal Li-F granites of the Janchivlan Pluton produced small domal intrusions composed of microcline-albite, amazonite-albite and albite-lepidolite granites. The $\mathrm{Sn}-\mathrm{Ta}-\mathrm{Nb}$ mineralization is associated with albite-lepidolite granites.

The rare-metal granites of the Baikal region and Central Mongolia of contrasting ages show an identical geochemical signature of $\mathrm{Li}-\mathrm{F}$ granites. It is expressed by increase in $\mathrm{F}, \mathrm{Li}, \mathrm{Rb}, \mathrm{Cs}, \mathrm{Sn}, \mathrm{Be}, \mathrm{Ta}$ and $\mathrm{Pb}$ and decrease in $\mathrm{Sr}, \mathrm{Ba}, \mathrm{Zn}, \mathrm{Zr}$, Th and $\mathrm{U}$ contents in course of multiphase intrusions formation. The geochemical data confirm the magmatic model for genesis of the studied rare-metal Li-F granites. However, this process of magma differentiation was terminated with formation of albitites, microclinites and muscovite greisens. The whole-rock geochemistry and isotopic composition of the granites points to the Precambrian crust of the Baikal region $\left(\mathrm{T}_{2 \mathrm{DM}}=1.0-1.3 \mathrm{Ga}\right)$ as the most likely source. We propose the formation of the initial granitic melts due to anatexis of the higher levels of the continental crust, with fluids released during granulite-facies metamorphism in the lower crust. The rare-metal Li-F granites of the studied provinces are intraplate formations geochemically different from the Early Paleozoic collisional granitoids. This could be caused by the influence of deep-seated source on the occurrence of rare-metal magmatism.
\end{abstract}

Keywords: rare-metal granites, Li-F granite, Late Paleozoic, Early Mesozoic, Mongolia, Baikal region

Received: 22 September, 2015; accepted: 26 February, 2016; handling editor: K. Schulmann

\section{Introduction}

Rare-metal granitoids have a distinct place in the Central Asian Orogenic Belt (CAOB) or Altaids (e.g., Şengör et al. 1993; Kovalenko et al. 1999), a large accretionary complex surrounded by the Siberian Craton to the west and the North China with Tarim cratons to the south (Kovalenko et al. 2004; Windley et al. 2007). The CAOB is characterized by intense Phanerozoic granitoid magmatism, including post-orogenic and intraplate granitoids of Late Paleozoic-Early Mesozoic age that form large batholiths, (e.g. Angara-Vitim, Daurian-
Khentei) surrounded by rift zones with bimodal basalt magmatism, subalkaline and alkaline granite plutons and rare-metal granites (Fig. 1). The origin of this large granitoid province is still controversial. Some researchers (Jahn et al. 2004, 2009) have suggested a role of juvenile component in granitoid origin. Others (Yarmolyuk et al. 2013, 2014) ascribed the major role to an activity of a mantle plume, triggering the intraplate magmatism, interaction between asthenospheric and lithospheric mantle, continental collision, and melting of crustal rocks. After Li et al. (2013) the early Mesozoic granitoids originated during subduction processes and 


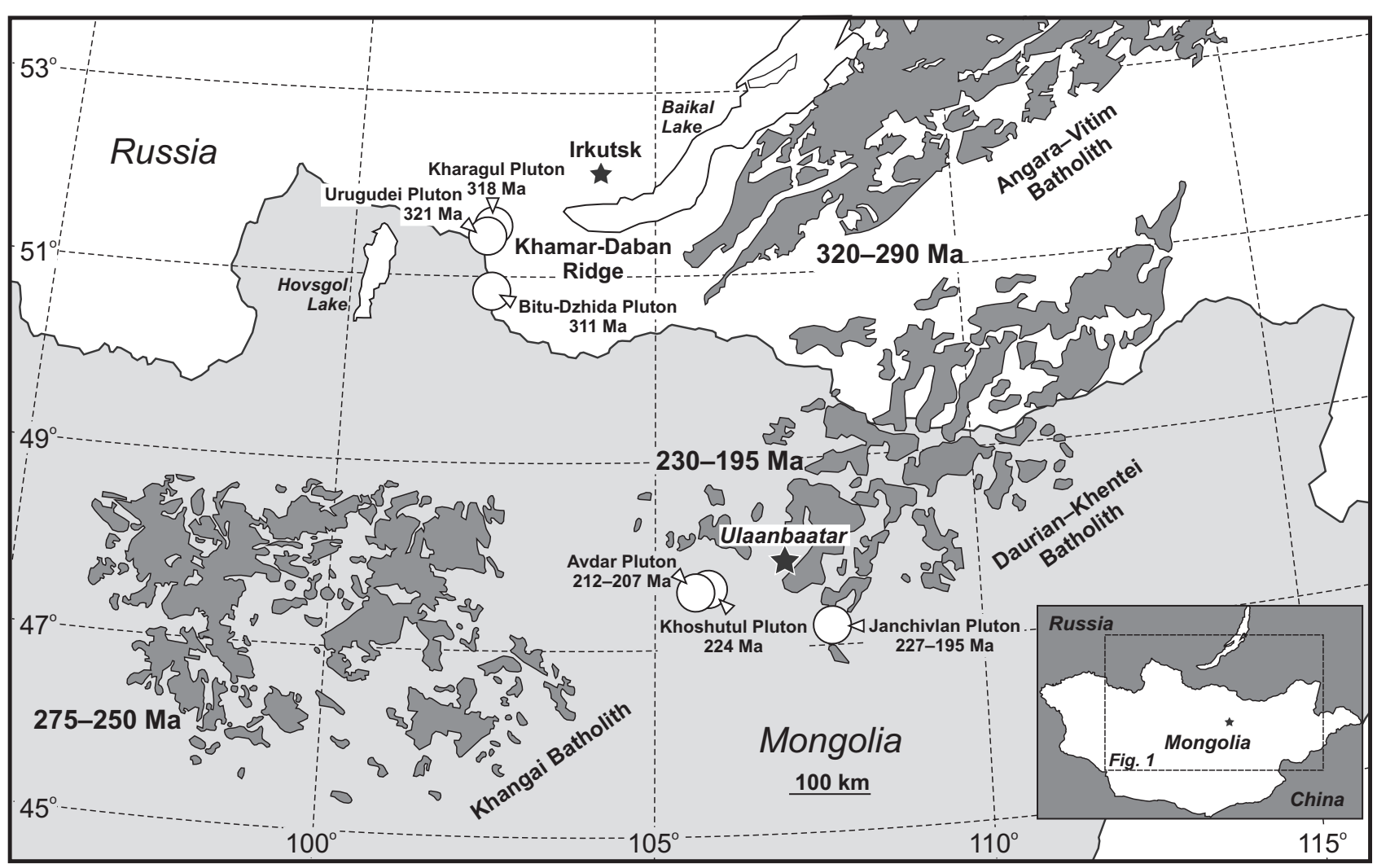

Fig. 1 Position and the age of the studied Late Paleozoic and Early Mesozoic rare-metal granitoids and large batholiths of Central Mongolia and Baikal region, after Yarmolyuk and Kovalenko (2003). The large granite batholiths are shown in gray, rare-metal granitic plutons by white circles.

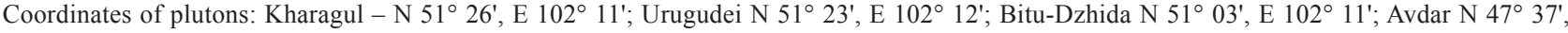
E $105^{\circ} 27^{\prime}$; Janchivlan N $47^{\circ} 33^{\prime}$, E $107^{\circ} 35^{\prime}$

formed in active continental margin or back-arc environment (Donskaya et al. 2013).

Rare-metal granites are identified as those with high concentrations of F, Li, Rb, Cs, Be, Sn, W, Ta, Nb, Zr, and REE (Tauson 1977; Kovalenko 1977, 1978) and the metallogenically specialized granites (Tischendorf and Palchen 1985). There is a number of classification schemes of these granites. Kovalenko (1977) and Tauson (1977) recognized two different geochemical types of rare-metal granites, peralkaline (agpaitic) and metaluminous to peraluminous (plumasitic or Li-F). Each of these granite types has a distinctive set of trace-element characteristics and associated mineral deposits. The $\mathrm{Li}-\mathrm{F}$ granites are enriched in $\mathrm{Li}, \mathrm{Rb}$, $\mathrm{Ta}, \mathrm{Sn}, \mathrm{U}$, and $\mathrm{F}$ whereas the peralkaline granites are extremely enriched in $\mathrm{Zr}, \mathrm{Nb}$, LREE and F. In general, the peralkaline rare-metal granites appear to be part of the anorogenic group of granites (A-type) identified by Loiselle and Wones (1979), Collins et al. (1982), and Whalen et al. (1987).

After Linnen and Cuney (2005), there are three types of rare-metal granites: (1) peralkaline rare-metal granites characterized by very high abundances of $\mathrm{F}$, $\mathrm{REE}, \mathrm{Y}, \mathrm{Zr}$ and $\mathrm{Nb}$ and high concentrations of $\mathrm{Th}, \mathrm{Sn}$, $\mathrm{Be}, \mathrm{Rb}$ and $\mathrm{U}$, high $\mathrm{Nb} / \mathrm{Ta}$ ratios and low $\mathrm{P}$ contents that are rich in Fe and emplaced in anorogenic settings; (2) metaluminous rare-metal granites typically having intermediate REE, Y, Zr, Hf and Th, associated with high-K calc-alkaline magma series and occurring in postorogenic and anorogenic settings; (3) peraluminous rare-metal granites, known as Li-F granites (Kovalenko 1977), having highly variable mineralogy, low $\mathrm{Zr} / \mathrm{Hf}$ and $\mathrm{Nb} / \mathrm{Ta}$ ratios, and forming postorogenic plutons in continental collision belts.

Despite numerous experimental and geochemical works as well as fluid-inclusion studies (Kovalenko 1977; Christiansen et al. 1988; Taylor 1992; Štemprok and Seltmann 1994; Dostal and Chatterjee 1995; Raimbault et al. 1995; Reyf et al. 1999; Antipin et al. 1999, 2011; Kostitsyn 2001; Badanina et al. 2010; $\mathrm{Gu}$ et al. 2010), the origin of $\mathrm{Li}-\mathrm{F}$ granites is still open to discussion. The debate concerns the sources of granite magma, mechanism of enrichment in rare elements, and role of fluids in ore concentration. The Li-F granites typically represent the latest pulses of multiphase late/postorogenic to anorogenic granite complexes.

The discovery of subvolcanic and volcanic glassy equivalents of the topaz-bearing granites - ongonites (Kovalenko and Kovalenko 1976; Kovalenko 1977) char- 


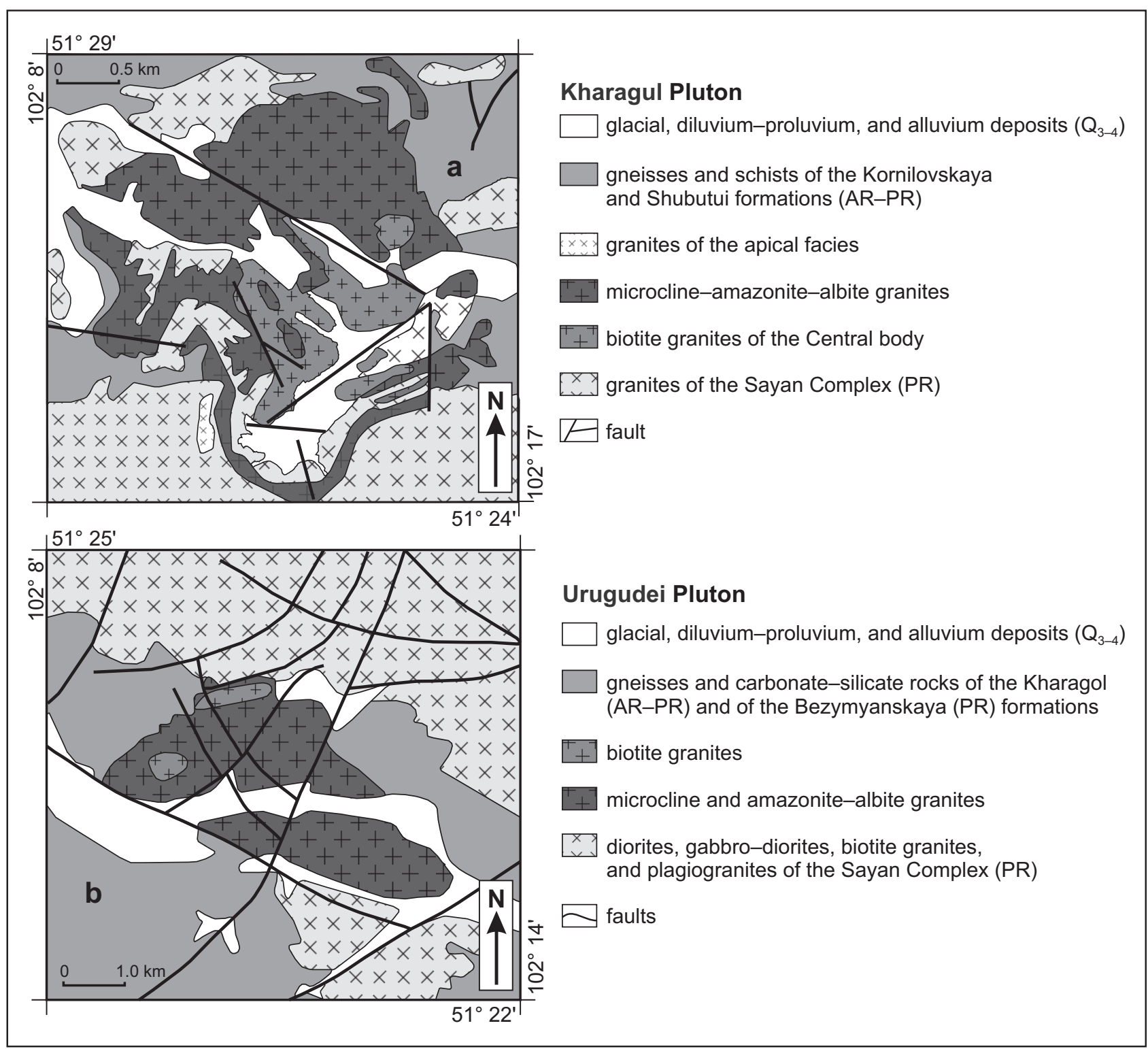

Fig. 2 Schematic geologic structure of the Kharagul (a) and Urugudei (b) rare-metal granitoid plutons (Antipin and Perepelov 2011).

acterized by enrichment of $\mathrm{Li}, \mathrm{Rb}$ and $\mathrm{Cs}$ and related ore elements ( $\mathrm{Sn}, \mathrm{W}, \mathrm{U}, \mathrm{Nb}$ and $\mathrm{Ta}$ ), provides strong support for the magmatic model. In this paper we discuss the geochemistry, magma sources and rare-metal mineralization of granites occurring in the Late Paleozoic and Early Mesozoic granitoid areas surrounding the Angara-Vitim and Daurian-Khentei batholiths in Central Mongolian and Russian tracts of the CAOB.

\section{Geological setting and petrography}

Late Paleozoic rare-metal granites (e.g. Kharagul, Urugudei and Bitu-Dzida) occur in the Baikal region, Russia and Early Mesozoic granites (e.g. Janchivlan and Avdar) in the marginal part of the Daurian-Khentei Batholith, Mongolia (Fig. 1) ${ }^{1}$.

\subsection{The Kharagul Pluton}

The Kharagul and Urugudei plutons are situated in the western part of the Khamar-Daban Ridge near the Urugudei peak $(2758 \mathrm{~m})$. The rock exposures range from 8 to $10 \mathrm{sq} . \mathrm{km}$ and both can be classed as multiphase

\footnotetext{
${ }^{1}$ In this paper we use not widely accepted names for granite rocks proposed by Kovalenko et al. (1971). Those composed predominantly of $K$-feldspar and albite, with accessory amounts of Li-mica, are termed "microcline-albite and amazonite-albite". If mica content exceeds $1 \mathrm{vol} . \%$, granites are named "lepidolite-albite or zinnwaldite-albite", as appropriate.
} 


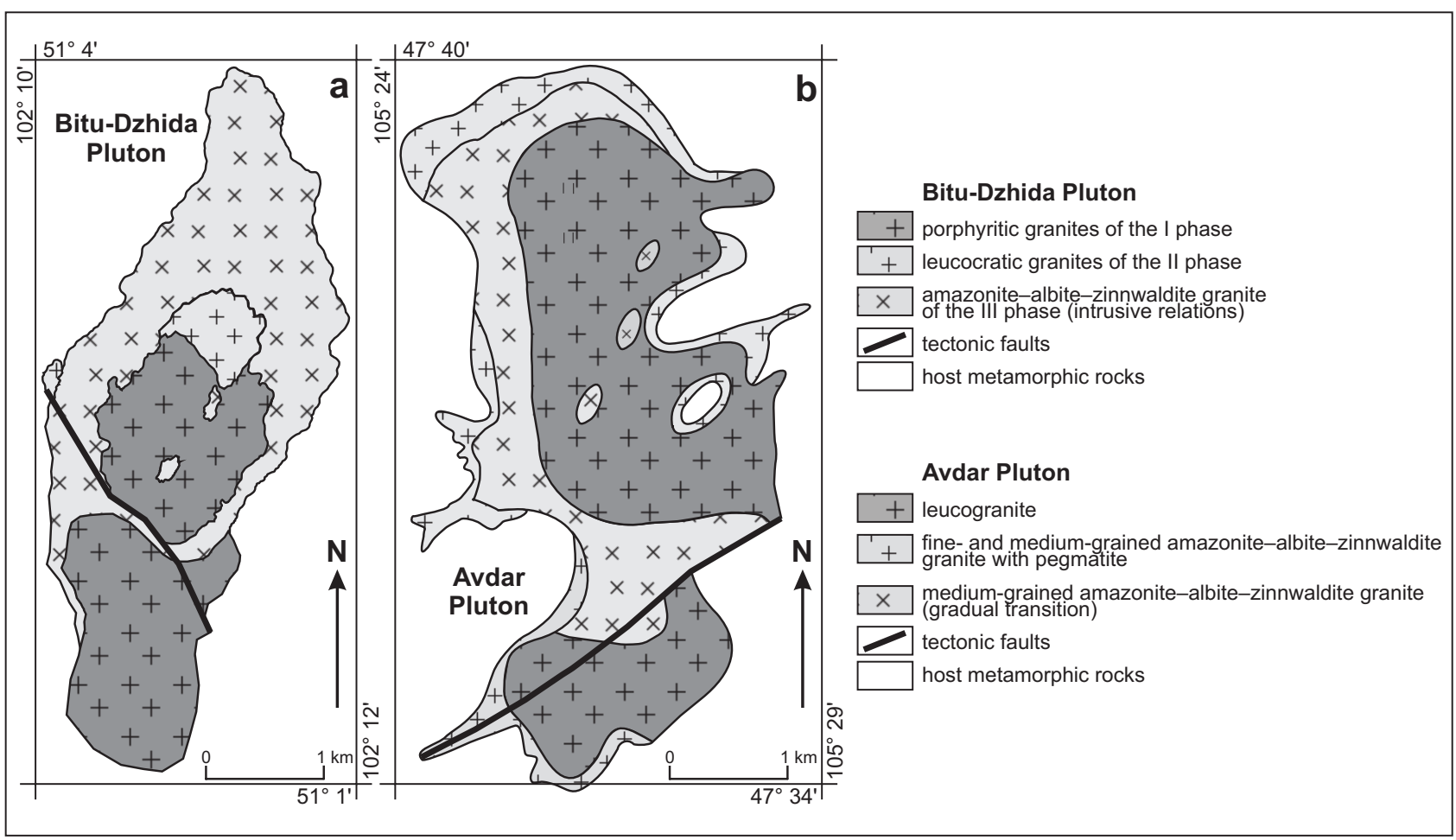

Fig. 3 Schematic geologic structure of the Bitu-Dzhida (Antipin and Perepelov 2011) (a) and Avdar (Kovalenko et al. 1971; Antipin 1977) (b) rare-metal granite plutons.

intrusions. The Kharagul Pluton (Fig. 2a) shows a more complicated structure and greater diversity of petrographic rock types. It is an intrusive body surrounded by a series of dikes within the metamorphic rocks of the Khamar-Daban Group of the Riphean age in which the Shubutui and Kornilovskaya flysh formations are distinguished. The early intrusive phase is formed by medium- to fine-grained, in places porphyritic, biotite granites that grade into quartz syenites. In addition to feldspars, quartz, and biotite, the early granites contain fluorite (up to 1.4 vol. \%) and magnetite (up to 1.2 $\%)$. The late phase in the northern part of the Kharagul Pluton is made up of medium-grained topaz-bearing microcline and amazonite-albite granites forming an intrusion extending nearly $\mathrm{E}-\mathrm{W}$. It is accompanied by a series of dikes, most of which occur among the countryrock gneisses and schists and are probably apophyses of the deep part of the pluton not exposed on surface. The largest of the dikes is $3 \mathrm{~km}$ long and has a thickness ranging from 15 to $70 \mathrm{~m}$.

The feldspars of the late granites are cross-hatched microcline and albite $\left(\mathrm{Ab}_{3-7}\right)$, and the micas are $\mathrm{Li}$ varieties, protolithionite and zinnwaldite, occasionally associated with lepidolite and Li phengite-muscovite in the apical part of the intrusion. In contrast to the granites of the early phase, the late rare-metal granites contain topaz (up to 1.5 vol. \%), columbite-tantalite, cassiterite, and rare monazite and cyrtolite. The petrographic peculiarities of these rocks are that the degree of quartz idiomorphism relative to other minerals is higher, albite is significantly more abundant than microcline, and topaz occurs.

\subsection{The Urugudei Pluton}

The Urugudei Pluton (Fig. 2b) is located on south slopes of the Urugudei peak and its structure is rather simple. The northern and western parts of the intrusion comprise abundant coarse- and medium-grained biotite granites, which can be assigned to the early phase. Microcline and amazonite-albite granites, which dominate at the presentday exposure level, were formed during the late-stage development of the intrusion. An important mineralogical feature of the Urugudei Pluton is the presence of 1.5-3.5 vol. \% of tourmaline in both phases. It coexists with fluorite in the early biotite granites and topaz in the late amazonite-albite granites.

The two plutons of the Khamar-Daban Range have similar mineral compositions of early biotite and late rare-metal Li-mica-bearing granites (Antipin and Perepelov 2011). They differ from each other mainly by the quantitative proportions of major minerals. The biotite granites of the Urugudei Pluton are richer in quartz (by 10 vol. \%) and poorer in plagioclase compared to the biotite granites of the Kharagul Pluton. The content of albite in the late amazonite-albite granites of the Urugudei intrusion is lower compared to the rare-metal granites of the 
Kharagul intrusion. High contents of tourmaline, fluorite or topaz and thus, high fluorine and boron contents, are distinctive geochemical features of the magmas parental to the Urugudei granites.

\subsection{The Bitu-Dzhida Pluton}

The Bitu-Dzida Pluton (Fig. 3a) is situated at the Russia-Mongolia border within Neoproterozoic schists of the Bitu-Dzhida Fm. The pluton is oval-shaped, curved, and elongated in a north-south direction. It is $\sim 5 \times 2 \mathrm{~km}$ in size, and its exposed area is $9 \mathrm{~km}^{2}$. Three main intrusive phases were distinguished. According to Antipin and Perepelov (2011), the first phase was Late Carboniferous ( $311 \pm 10 \mathrm{Ma}$, whole-rock Rb-Sr method). The first phase is represented by small outcrops in the Russian part of the Pluton and considerable exposures of medium-grained and porphyritic biotite granites in Mongolia. The second phase is made up of leucocratic granites. The amazonitealbite-zinnwaldite rare-metal granites of the final, third phase are most abundant at the present-day erosion level in the Russian part of the Pluton. Fluorite occurs in some granites of all the phases and pegmatoid amazonite-albite granites (Fig. 4). Topaz is rare and was found only in the final-stage magmatic products. The development of the multiphase intrusion was closed by pegmatite formation and greisenization. The Bitu-Dzhida Pluton can be assigned to the same age group as the Urugudei (whole rocks, $\mathrm{Rb}-\mathrm{Sr}$ method, $321 \pm 5 \mathrm{Ma}$ ) and Kharagul (whole rocks, $\mathrm{Rb}-\mathrm{Sr}$ method, $318 \pm 7 \mathrm{Ma}$ ) plutons of rare-metal granites in the Khamar-Daban Range.

\subsection{The Avdar Pluton}

The Avdar Pluton (Fig. 3b) is located c. $150 \mathrm{~km}$ from Ulaanbaatar at the southwestern continuation of the Khoshutul Pluton and the accompanying series of dike rocks (Fig. 1). The Khoshutul Pluton is a multistage intrusion with whole-rock $\mathrm{Rb}-\mathrm{Sr}$ age of $224 \pm 10 \mathrm{Ma}$ (Odgerel and Antipin 2009). Host rocks are represented by upper and partly middle section of the Paleozoic Mandal Group.

Shape of the Avdar Pluton is elliptical, and the area of

Fig. 4 Backscattered- electron image of fluorite in granite of the first (BD 2421/1) and third (BD 2429) phases of the Bitu-Dzhida Pluton. Bt - biotite, Ab - albite, Kfs - potassium feldspar, Qtz - quartz, Ilm - ilmenite, Ap - apatite, Fl - fluorite. the rock outcrops does not exceed $10 \mathrm{~km}^{2}(6 \times 2.5 \mathrm{~km})$. The Avdar Pluton is located within a brachyanticlinal structure, and is elongated in a longitudinal direction. The northern and eastern parts are concordant with host rocks, and western contact is sharply discordant. The internal zonal structure of the Pluton and its relationship with host rocks suggest a dome-shaped intrusion, the apical part of which is located near the top of the Avdar Uul (Kovalenko et al. 1971; Antipin 1977). The central largest area is occupied by medium-grained biotitebearing leucogranites, rimmed in the east and north by zone of intermittent medium-grained amazonite-albite granites that also occur in the apical parts. Directly near the exocontact, narrow zone of inequigranular aplitic granite with numerous schlieren of quartz-microcline pegmatites has been observed. Contacts between different types of the Avdar granites are usually gradual. A zonal structure is reflected that the rocks in hanging inner contact are represented by pegmatoid granite with amazonite, and in its footwall they gradually pass into aplitic granites and then to felsites with chilled zones and fluidal texture.

Pelitic xenoliths within the Pluton were transformed to quartz-cordierite-andalusite-biotite- magnetite \pm plagioclase hornfelses. The highest degree of thermal metamorphism is noted in small xenoliths metamorphosed into zinnwaldite-fluorite-magnetite-quartz \pm K-feldspar hornfelses.

The first data on the age of leucogranite and amazonite-albite granite of the Avdar Pluton were obtained by $\mathrm{K}-$ Ar dating of biotite (172-222 Ma, five determinations of Kovalenko et al. 1971). The $\mathrm{Rb}-\mathrm{Sr}$ whole rock-mineral (biotite) isochron age of 202-205 $\pm 2 \mathrm{Ma}$ (Kovalenko et al. 1999) confirms that it belongs to the Early Mesozoic magmatic stage.

Plagioclase $\left(\mathrm{An}_{4-18}\right)$ in leucogranites of the Avdar Pluton accounts typically for less than 25 vol. \%, and it occurs in the prismatic and small lath-shaped grains. Microcline ( $\left.\mathrm{Ort}_{77} \mathrm{Ab}_{23}\right)$ forms rather euhedral grains
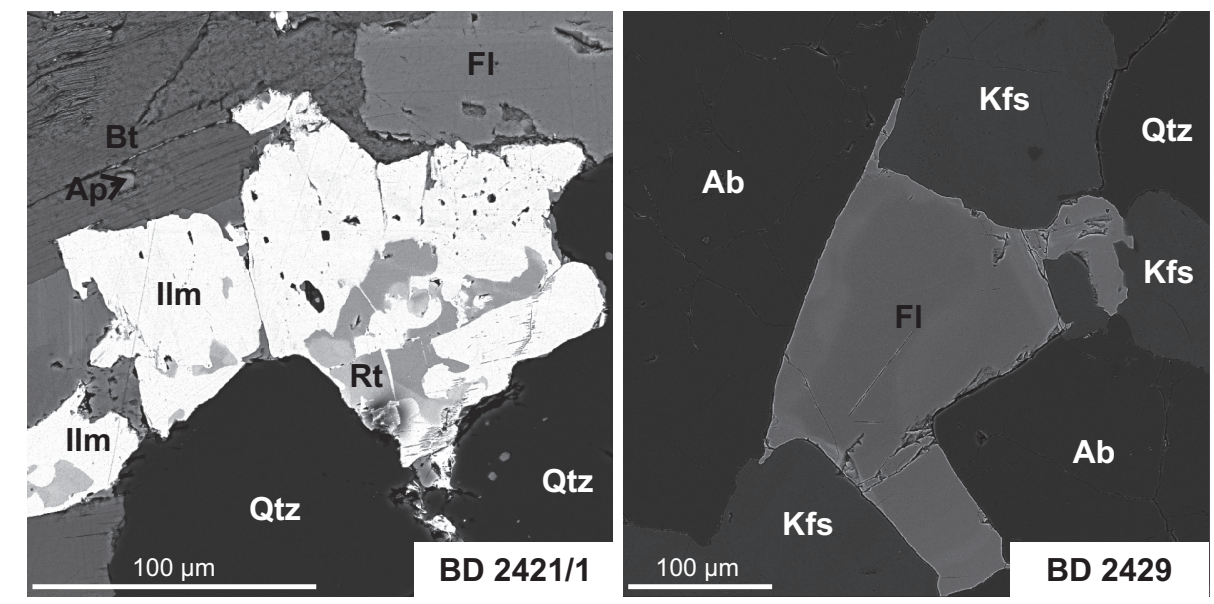


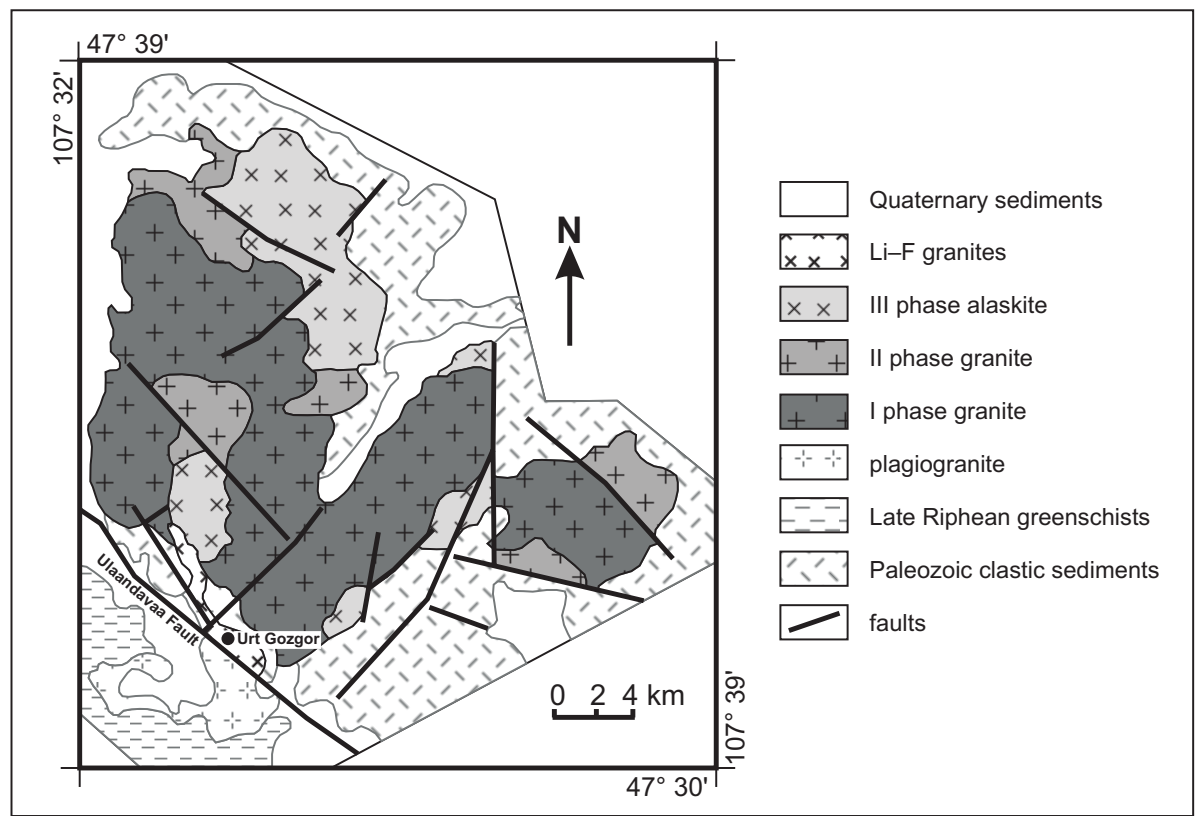

Fig. 5 Simplified geological map of the Janchivlan Pluton (modified after Kovalenko et al. 1971). with rough edges and contains perthites in the central parts. The total content of alkali feldspar in leucogranites approaches $35-36 \%$, and the amount of biotite is usually c. $2.5-3.0 \%$. Typical accessory minerals in leucogranites are magnetite, ilmenite, fluorite, zircon and monazite.

Medium-grained amazonite-albite granites have a more sodic plagioclase $\left(\mathrm{An}_{2-7}\right)$ and microcline is characterized by a lower content of albite $\left(\mathrm{Ort}_{81-85}, \mathrm{Ab}_{15-19}\right)$. Micas are of lithium-iron type. The amazonite-albite granites are characterized by the following accessory minerals: fluorite, zircon, ilmenite, magnetite, and columbite-tantalite.

\subsection{The Janchivlan Pluton}

The Janchivlan Pluton is located at the southern tip of the Early Mesozoic Daurian-Khentei Batholith (e.g. Kovalenko et al. 1971; Antipin 1977; Gerel 1990; Koval 1998). Marginal parts of the Batholith host small shallow intrusions of alkaline and subalkaline granite series with $\mathrm{Li}-\mathrm{F}$ peraluminous rare-metal granites as the final products. These intrusions are unfoliated, discordant and surrounded by contactmetamorphic aureoles of hornfels or have tectonic contacts. The regional structure of the Daurian-Khentei Batholith is characterized by strike-slip faults that display dominant northeast trends. The Janchivlan Pluton (Fig. 5) occupies an area of about 1,100 sq. km. Host rocks consist of Precambrian quartz-chlorite-sericite schists with quartzite lenses, Middle Paleozoic sandstones and siltstones, intruded by plagiogranites of Early Mesozoic age. The main trend of the Paleozoic structures is conformable with the strike of the Khentei synclinorium.

In the Janchivlan Pluton, Ushakov and Boguslavsky (1969) have distinguished four intrusive phases, while Kovalenko et al. (1971) listed only three main ones. Yarmolyuk et al. (2002) reported zircon $\mathrm{U}-\mathrm{Pb}$ ages of $217 \pm 52 \mathrm{Ma}$ and $227 \pm 8 \mathrm{Ma}$, for the first and second phases respectively and a whole-rock $\mathrm{Rb}-\mathrm{Sr}$ age of $195 \pm 0.6 \mathrm{Ma}$ for the Li-F granites (amazonite-albite granites). The Pluton shows a complicated shape with its apex directed to the northeast, the direction of the Mesozoic fault system. Faults divide the Pluton into three segments: western, central and eastern.

The dominant central part of this Pluton is composed of the first phase porphyritic coarse-grained granites with abundant miarolitic pegmatites. The second phase of equigranular medium-grained biotite and muscovite-biotite granites occur as two small outcrops in the center, and the third phase is represented by leucogranites (biotite alaskites of Kovalenko et al. 1971) that crop out in the northern and central parts of the Pluton. Lithium-fluorine granites containing amazonite-albite, microcline-albite and lepidolite-albite assemblages form small bodies which intruded in the southern part of the Janchivlan Pluton known as Urt Gozgor outcrops, controlled by the Ulaandavaa Fault in the southern part of the Pluton (Fig. 5).

Porphyritic coarse-grained biotite granite of the first phase accounts for $c$. $60 \%$ of the intrusion. It contains $\mathrm{K}$-feldspar as phenocrysts $\left(\mathrm{Or}_{75} \mathrm{Ab}_{25}\right)$ and in groundmass $\left(\mathrm{Or}_{86} \mathrm{Ab}_{14}\right)$ (45-65 vol. \%), quartz (30-35\%), plagioclase $\mathrm{An}_{24-26}(10-15 \%)$, biotite (3-5\%) and amphibole (0-2\%); allanite, apatite, zircon, magnetite and ilmenite are accessory minerals. Biotite and leucocratic granites 
contain a number of miarolitic, well-differentiated pegmatites. The pegmatites are composed of quartz, $\mathrm{K}$ feldspar, plagioclase, and biotite, with accessory muscovite, beryl, topaz, tourmaline, zircon, allanite, magnetite, and molybdenite.

Second phase granites occupy c. $25 \%$ of the intrusion outcrop and are represented by medium-grained weakly porphyritic biotite-muscovite granite composed of K-feldspar $\left(\mathrm{Or}_{75} \mathrm{Ab}_{25} ; 40-45\right.$ vol. \%), plagioclase $\mathrm{An}_{20-25}$ (10-15\%), quartz (32-25\%), biotite (4-6\%) and muscovite $(2 \%)$, with accessory allanite, apatite, zircon and magnetite.

Third-phase leucogranites (biotite alaskites) occupy c. $15 \%$ of the outcrop and crop out mainly in the northeastern part of the Pluton. They are composed of K-feldspar (36-38 vol. \%), plagioclase $\mathrm{An}_{15-5}(15-23 \%$ ), quartz (38-40\%), biotite (3-4\%) and accessory minerals: topaz, fluorite, monazite, ilmenite, and magnetite. The Li-F granites are associated with the third phase. These microcline-albite and amazonite-albite granites occur in the southwestern part of the Pluton. The latter and the Urt Gozgor outcrop of rare-metal granites have asymmetric dome shapes elongated in a NW-SE direction. They occur along the large Ulaandavaa Fault and are fractured into same blocks by northeastern faults cross-cutting the Ulaandavaa Fault. Microcline-albite and amazonite-albite granites account for $c .6 \%$ and lepidolite-albite granites for $1 \%$ of the pluton. Microcline-albite granites are medium-grained rocks composed of quartz (40 vol. \%), perthitic K-feldspar (30.5\%), albite $\mathrm{An}_{2-10}(25.5 \%)$ and accessory mica: protolithionite and Li-phengite. Other accessory minerals are topaz, fluorite, zircon, monazite, columbite, xenotime, cassiterite and magnetite. Amazonite-albite granites are medium-grained, poorly porphyritic and composed of quartz (38-39 vol. \%), amazonite (35\%), albite (21\%) and mica (zinnwaldite), together with accessory topaz, fluorite, zircon, monazite, columbite and cassiterite (Gerel et al. 1999).

Albite-lepidolite granites are composed of quartz (23 vol. \%), albite (57\%), K-feldspar (14\%), lepidolite (4\%) and topaz (2-2.5\%). Some samples contain up to $10 \%$ topaz and up to $20 \%$ lepidolite. Albitites may reach even $90 \%$ of albite, $3 \%$ microcline, $3 \%$ quartz, $2.5 \%$ lepidolite and $0.4 \%$ topaz. Accessory minerals are fluorite, zircon, monazite, columbite, $\mathrm{Pb}$-pyrochlore and cassiterite. The structures range from fine-grained to porphyritic and pegmatitic (Kovalenko et al. 1971).

Albite, quartz, K-feldspar and Li-mica are the main rock-forming minerals of the $\mathrm{Li}-\mathrm{F}$ granites. Magmatic topaz is a common accessory mineral. Granite is greisenized; fluorite and cassiterite are common in all types of Li-F granites. Mica forms trend from siderophyllite in the first-phase granites to zinnwaldite and lepidolite in third-phase Li-F granites.

\section{Analytical methods}

\subsection{Whole-rock geochemistry}

Major-element oxides (wt. \%) were analyzed by Multichannel X-Ray Spectrometer SRM-25, "Orelnauchpribor", Russia at the Center of Isotope-Geochemical Studies, Vinogradov Institute of Geochemistry, Russian Academy of Sciences, Siberian Branch (IGS SB RAS). $\mathrm{Rh}$-anode has been used. The measurements were performed at a voltage of $30 \mathrm{kV}$ and a current of $40 \mathrm{~mA}$. Samples were homogenized by a fusion with lithium metaborate $\left(\mathrm{LiBO}_{2}\right)$ in an induction furnace in glassy carbon melting pot at $1100^{\circ} \mathrm{C}$. The ratio of sample to flux was 1:2. The calibration was carried out using SH1A (granite, Russia), SG-2 (granite, Russia), and JG-2 (granite, Japan) standards.

Trace elements were determined using Agilent 7700x Quadrupole ICP-MS at the "Baikal Nanotechnology Center" of the Industrial Park at the Irkutsk State Technical University. For measurements were chosen optimal conditions: plasma power of $1550 \mathrm{~W}$, the reflected power $11 \mathrm{~W}$, plasma gas flow $15.01 \mathrm{l} / \mathrm{min}$; the integration time was $0.1 \mathrm{~s}$ per data point. Sample fusion with anhydrous lithium metaborate $(1: 4)$ was performed in a glassy melting pot with subsequent decomposition by a $\mathrm{HF}$ and $\mathrm{HNO}_{3}$ (both supra-pure (MERCK)) acid mixture. The sample weight was $100 \mathrm{mg}$, and the final dilution factor of sample solutions $\left(3 \% \mathrm{HNO}_{3}\right)$ was $10,000 \times$. The accuracy was checked using the Geological Survey of Japan standards JG-3 (granite) and JR-1 (rhyolite). Emission determination of fluorine was carried out by the Diffraction Spectrometer DFS-458S (Russia) with photodiode arrays MAES (Vasil'yeva and Shabanova 2012) using the integrated software ARDES (Spectr-Inform Ltd., Russia). Lithium was analyzed by flame photometry.

In addition, representative samples of the Janchivlan Pluton were analyzed at the Department of Geoscience, Shimane University, and Institute of Mineralogy, Petrology and Economic Geology, Tohoku University, Japan. Major-element chemical analyses were carried out using the RIX-2000 XRF, Li by ion-electrode method and Rb by atomic absorption spectrophotometry. Remaining trace elements were determined by ICP-MS Agilent $7500 \mathrm{cs}$ system, housed at the Shimane University, following alkali fusion and acid digestion methods, described by Kimura et al. (1995).

\section{2. $\mathrm{Sr}-\mathrm{Nd}$ isotopes}

The isotopic composition of $\mathrm{Sr}, \mathrm{Nd}$ and $\mathrm{Pb}$ for the BituDzhida Pluton was performed at the IGS SB RAS. For isotopic analyses, $100 \mathrm{mg}$ of the sample powder were dissolved in a Teflon beaker with $\mathrm{HNO}_{3}-\mathrm{HF}-\mathrm{HClO}_{4}$ 

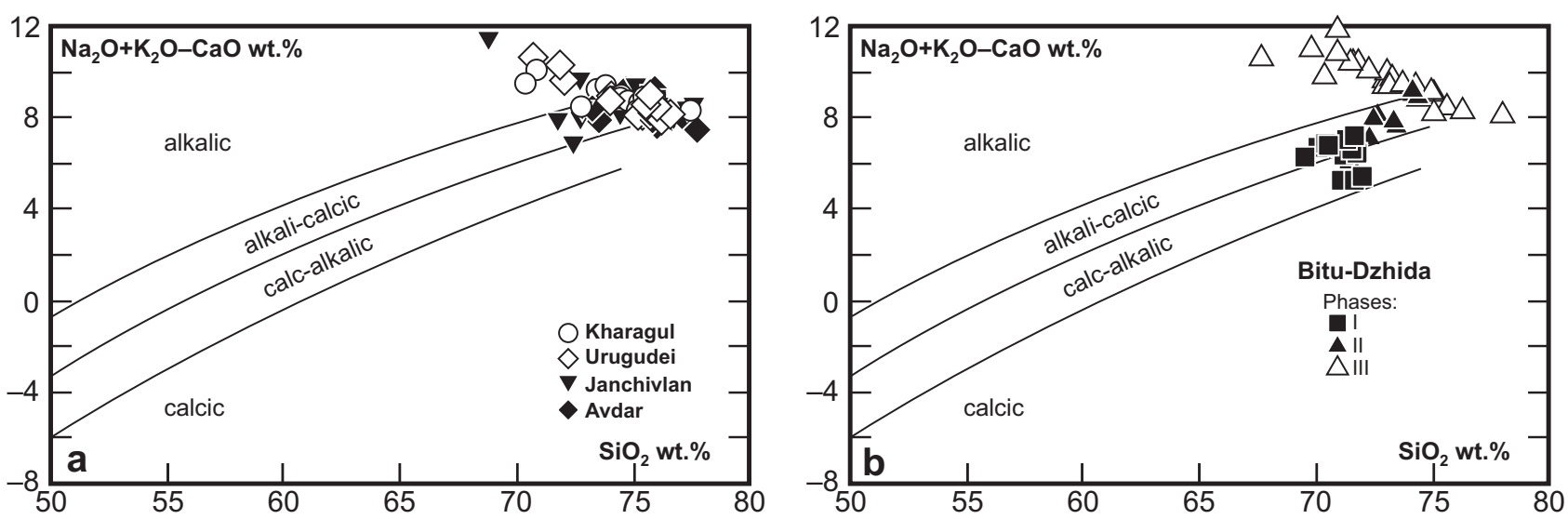

Fig. 6 Classification diagrams of Late Paleozoic and Early Mesozoic rare-metal granitoids of Central Mongolia and Baikal region in coordinates $\mathrm{SiO}_{2}$ vs. $\left(\mathrm{Na}_{2} \mathrm{O}+\mathrm{K}_{2} \mathrm{O}-\mathrm{CaO}\right)$ (Frost et al. 2001).

acid mixture and heated using a microwave oven. For separation of $\mathrm{Sr}$ and $\mathrm{Nd}$, EIChroM Industries II (USA) resin was used. Separation of rare earths, $\mathrm{Sr}$ and $\mathrm{Nd}$ was performed using TRU Spec and Ln Spec resins (Pin and Zalduegui 1997). For Sr isolation, Sr Spec resin was employed (Pin et al. 1994).

The measurement of the $\mathrm{Nd}$ and $\mathrm{Sr}$ isotopic ratios was carried out by Finnigan MAT 262 Thermal Ionization Mass Spectrometer (TIMS). The accuracy of the analysis was checked by measuring the SRM $987\left({ }^{87} \mathrm{Sr} /{ }^{86} \mathrm{Sr}=\right.$ 0.710250 certified) and $\mathrm{JNd}-1\left({ }^{143} \mathrm{Nd} /{ }^{144} \mathrm{Nd}=0.512100\right.$ certified) standards. The values obtained in parallel experiments were: $0.710255 \pm 15(\mathrm{n}=19)$ for the SRM 987 and $0.512101 \pm 6(\mathrm{n}=34)$ for JNd-1. During mass spectrometric measurements, the isotope ratios were normalized to ${ }^{88} \mathrm{Sr} r{ }^{86} \mathrm{Sr}=8.375209$ and ${ }^{146} \mathrm{Nd} /{ }^{144} \mathrm{Nd}=0.7219$, respectively. The $\varepsilon N d$ values and two-stage Depleted Mantle $\mathrm{Nd}$ model ages $\left(\mathrm{T}_{2 \mathrm{DM}}\right)$ were calculated according to Faure (1986) and Keto and Jacobsen (1987). Concentrations of $\mathrm{Rb}, \mathrm{Sr}, \mathrm{Sm}, \mathrm{Nd}$ (ppm) were determined by the ICP-MS.

\subsection{Pb isotopes}

Isolation of $\mathrm{Pb}$ was achieved using the BioRad-AG1X8 resin and slightly modified procedure of Krogh (1973).
The isotopic compositions for the Bitu-Dzhida Pluton were acquired on multicollector ICP-MS NEPTUNE Plus at the IGS SB RAS using dual isotope dilution method with ${ }^{207} \mathrm{~Pb}+{ }^{204} \mathrm{~Pb}$ tracer. Optimization of the isotopic composition of the tracer is made with the advice (Galer 1999; Rudge et al. 2009). The measurements were performed with the correction for ${ }^{204} \mathrm{Hg}$. The background level did not exceed $3 \times{ }^{208} \mathrm{~Pb} \times 10-15 \mathrm{~A},{ }^{202} \mathrm{Hg}$ in $\mathrm{Pb}$ spectrum averaged $2 \times 10-15 \mathrm{~A}$. The intensity of the ${ }^{208} \mathrm{~Pb}$ ion current was not less than $3 \times 10-11 \mathrm{~A}$. Measurements of standard sample NIST SRM-981 $(\mathrm{n}=27)$ gave ${ }^{206} \mathrm{~Pb} / 204 \mathrm{~Pb}=$ $16.9376 \pm 0.0022 ;{ }^{207} \mathrm{~Pb} /{ }^{204} \mathrm{~Pb}=15.4918 \pm 0.0022$; ${ }^{208} \mathrm{~Pb} /{ }^{204} \mathrm{~Pb}=36.695 \pm 0.006$. Accuracy of analysis $(2 \sigma)$ was $0.017-0.019 \%$.

For some samples of the Bitu-Dzhida Pluton Pb isotopic characteristics were obtained using a TIMS Finnigan MAT 262, considering the mass fractionation for isotopic standard NBS 981. The isotopic composition of $\mathrm{Pb}$ was measured in the single-mode. The correctness of the analysis was checked by measuring the standard sample SRM-981 $\left({ }^{208} \mathrm{~Pb} /{ }^{204} \mathrm{~Pb}=36.722,{ }^{207} \mathrm{~Pb} /{ }^{204} \mathrm{~Pb}=15.492\right.$, ${ }^{206} \mathrm{~Pb} /{ }^{204} \mathrm{~Pb}=16.937$ certified). The measured SRM-981 standard in parallel experiments gave $36.580 \pm 0.008$, $15.453 \pm 0.004,16.908 \pm 0.005(\mathrm{n}=33)$.
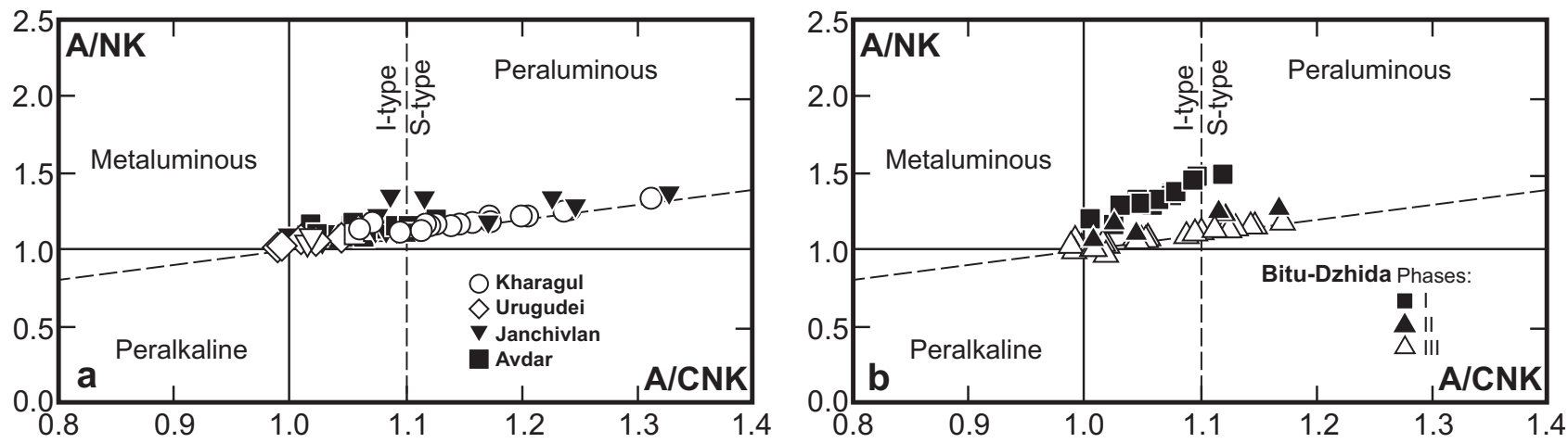

Fig. 7 The A/NK - A/CNK plot for the studied rare-metal granitoids (Shand 1943). 


\section{Whole-rock geochemistry}

\subsection{Kharagul and Urugudei plutons}

The development of multiphase intrusions from early biotite granites to late amazonite-albite granites with $\mathrm{Li}-\mathrm{F}$ mica was accompanied by an increase in $\mathrm{SiO}_{2}$ (Fig. 6a) and, especially, $\mathrm{Na}_{2} \mathrm{O}$ contents, whereas the level of $\mathrm{FeOt}, \mathrm{CaO}$, and $\mathrm{K}_{2} \mathrm{O}$ declined (Tab. 1) (Antipin and Perepelov 2011). In the same direction, i.e. from the earlier to the late granites, increase also the $\mathrm{Al}_{2} \mathrm{O}_{3}$ contents and, accordingly, $\mathrm{A} / \mathrm{NK}$ and A/CNK (Fig. 7a). Geochemical evolution included an increase in $\mathrm{F}, \mathrm{Li}, \mathrm{Rb}, \mathrm{Cs}, \mathrm{Sn}, \mathrm{Be}, \mathrm{Ta}$, and $\mathrm{Pb}$ and a decrease in $\mathrm{Ba}, \mathrm{Sr}, \mathrm{Zn}$, $\mathrm{Zr}$, Th and U contents. Similar evolution is also characteristic of the subvolcanic rocks, which underlines the genetic relation of the whole intrusive-dike complex of the Khamar-Daban Province. Significant differences were detected in the distribution of $\mathrm{K}, \mathrm{Ba}, \mathrm{Sr}$, and $\mathrm{Zr}$ between the calc-alkaline granitoids and raremetal Li-F granites (Antipin and Perepelov 2011).

Kovalenko et al. (1999) reported whole-rock $\mathrm{Rb}-\mathrm{Sr}$ isochron age of $318 \pm 7 \mathrm{Ma}$ for the main granite varieties of the Kharagul Pluton with an initial ${ }^{87} \mathrm{Sr} /{ }^{86} \mathrm{Sr}$ isotopic ratio $0.711 \pm 0.016(2 \sigma)$. A large error in the initial strontium isotope composition is due to high $\mathrm{Rb} / \mathrm{Sr}$ ratios. The whole-rock $\mathrm{Rb}-\mathrm{Sr}$ age of the biotite and amazonite-albite granites of the Urugudei Pluton is $321 \pm 5$ Ma (Kostitsyn 2001). The same author summarized isotopic data for both intrusions and obtained a single isochron with an age of $319 \pm 3 \mathrm{Ma}$ and $\left({ }^{87} \mathrm{Sr} /{ }^{86} \mathrm{Sr}\right)_{0}=$ $0.705 \pm 0.008$.
Tab. 1 Whole-rock composition of granites of the Kharagul and Urugudei plutons

\begin{tabular}{|c|c|c|c|c|c|c|c|}
\hline \multirow{3}{*}{$\begin{array}{l}\text { Sample } \\
\text { Plutons } \\
\text { Phase }\end{array}$} & KHR 612 & KHR 649 & KHR 637 & KHR 603 & UD 2005 & Z 34 & UD 2008 \\
\hline & \multicolumn{4}{|c|}{ Kharagul } & \multicolumn{3}{|c|}{ Urugudei } \\
\hline & I phase & II phase & & & I phase & II phase & \\
\hline $\mathrm{SiO}_{2}(\%)$ & 72.83 & 74.53 & 77.51 & 73.87 & 75.23 & 70.69 & 72.02 \\
\hline $\mathrm{TiO}_{2}$ & 0.10 & 0.04 & 0.02 & 0.05 & 0.12 & 0.06 & 0.08 \\
\hline $\mathrm{Al}_{2} \mathrm{O}_{3}$ & 14.38 & 14.60 & 12.67 & 15.30 & 12.90 & 16.30 & 14.47 \\
\hline $\mathrm{Fe}_{2} \mathrm{O}_{3}$ & 0.62 & 0.02 & 0.17 & 0.32 & 0.52 & 0.72 & 0.72 \\
\hline $\mathrm{FeO}$ & 1.25 & 0.98 & 0.53 & 0.26 & 1.16 & 0.35 & 0.35 \\
\hline $\mathrm{MnO}$ & 0.08 & 0.07 & 0.06 & 0.08 & 0.06 & 0.06 & 0.07 \\
\hline $\mathrm{MgO}$ & 0.05 & 0.05 & 0.05 & 0.05 & 0.10 & 0.05 & 0.10 \\
\hline $\mathrm{CaO}$ & 0.60 & 0.20 & 0.05 & 0.05 & 0.40 & 0.30 & 0.65 \\
\hline $\mathrm{Na}_{2} \mathrm{O}$ & 4.46 & 4.79 & 4.28 & 5.52 & 3.82 & 7.17 & 5.65 \\
\hline $\mathrm{K}_{2} \mathrm{O}$ & 4.60 & 4.35 & 4.08 & 3.93 & 4.70 & 3.77 & 4.64 \\
\hline $\mathrm{P}_{2} \mathrm{O}_{5}$ & 0.02 & 0.02 & 0.02 & 0.02 & 0.03 & 0.03 & 0.09 \\
\hline LOI & 0.76 & 0.55 & 0.46 & 0.46 & 0.69 & 0.32 & 0.64 \\
\hline Total & 99.75 & 100.10 & 99.90 & 99.61 & 99.64 & 99.82 & 99.48 \\
\hline $\mathrm{Li}(\mathrm{ppm})$ & 220 & 460 & 220 & 530 & 140 & 550 & 270 \\
\hline $\mathrm{F}$ & 3000 & 3000 & 1500 & 5000 & 1000 & 5200 & 1400 \\
\hline $\mathrm{Be}$ & 9.7 & 9.2 & 5.6 & 8.9 & 6.9 & 10.8 & 10.9 \\
\hline $\mathrm{Zn}$ & 113 & 142 & 95 & 104 & 45 & 30 & 40 \\
\hline $\mathrm{Ga}$ & 32 & 40 & 36 & 51 & 26 & 45 & 41 \\
\hline $\mathrm{Ge}$ & 2.4 & 2.9 & 2.8 & 4.2 & 2.2 & 4.2 & 4.0 \\
\hline $\mathrm{Rb}$ & 381 & 542 & 488 & 763 & 329 & 714 & 996 \\
\hline $\mathrm{Sr}$ & 4 & 7 & 11 & 2 & 19 & 16 & 9 \\
\hline Y & 41 & 24 & 165 & 50 & 43 & 20 & 50 \\
\hline $\mathrm{Zr}$ & 368 & 75 & 102 & 86 & 134 & 46 & 74 \\
\hline $\mathrm{Nb}$ & 73 & 56 & 36 & 64 & 62 & 44 & 39 \\
\hline $\mathrm{Sn}$ & 22 & 41 & 19 & 48 & 6 & 13 & 14 \\
\hline Cs & 20.0 & 28.0 & 15.0 & 28.0 & 12.0 & 56.0 & 51.0 \\
\hline $\mathrm{Ba}$ & 11 & 22 & 51 & 11 & 68 & 62 & 42 \\
\hline $\mathrm{La}$ & 50.00 & 3.05 & 14.40 & 9.60 & 31.00 & 2.52 & 13.40 \\
\hline $\mathrm{Ce}$ & 116.00 & 10.00 & 33.00 & 28.00 & 68.00 & 10.10 & 41.00 \\
\hline $\operatorname{Pr}$ & 12.60 & 1.39 & 5.50 & 3.77 & 7.90 & 1.59 & 5.30 \\
\hline $\mathrm{Nd}$ & 47.00 & 5.60 & 23.00 & 14.50 & 29.00 & 6.70 & 19.00 \\
\hline Sm & 9.00 & 1.70 & 6.10 & 3.67 & 7.00 & 2.70 & 6.40 \\
\hline $\mathrm{Eu}$ & 0.09 & 0.02 & 0.05 & 0.02 & 0.16 & 0.05 & 0.04 \\
\hline $\mathrm{Gd}$ & 8.30 & 1.80 & 8.00 & 3.47 & 7.40 & 2.96 & 6.30 \\
\hline $\mathrm{Tb}$ & 1.23 & 0.35 & 1.48 & 0.64 & 1.25 & 0.70 & 1.31 \\
\hline Dy & 7.60 & 2.60 & 10.40 & 4.69 & 8.30 & 5.10 & 9.30 \\
\hline Ho & 1.53 & 0.57 & 2.39 & 1.03 & 1.68 & 1.09 & 1.91 \\
\hline Er & 4.93 & 2.22 & 9.00 & 3.92 & 5.10 & 3.96 & 6.80 \\
\hline $\mathrm{Tm}$ & 0.80 & 0.47 & 1.69 & 0.85 & 0.76 & 0.79 & 1.37 \\
\hline $\mathrm{Yb}$ & 6.10 & 4.25 & 13.20 & 7.70 & 5.20 & 6.80 & 11.50 \\
\hline $\mathrm{Lu}$ & 0.95 & 0.68 & 2.17 & 1.25 & 0.76 & 1.04 & 1.81 \\
\hline $\mathrm{Hf}$ & 10.7 & 5.6 & 9.0 & 9.0 & 5.0 & 4.8 & 7.9 \\
\hline $\mathrm{Ta}$ & 8.7 & 22.0 & 8.5 & 31.0 & 4.8 & 17.0 & 8.1 \\
\hline $\mathrm{Pb}$ & 50.0 & 84.0 & 82.0 & 102.0 & 33.0 & 49.0 & 73.0 \\
\hline Th & 31.0 & 19.0 & 27.0 & 21.0 & 56.0 & 9.3 & 13.6 \\
\hline $\mathrm{U}$ & 10.1 & 3.3 & 8.8 & 4.1 & 7.8 & 2.1 & 6.3 \\
\hline $\mathrm{K} / \mathrm{Rb}$ & 101 & 67 & 70 & 43 & 119 & 44 & 39 \\
\hline $\mathrm{Zr} / \mathrm{Hf}$ & 34 & 13 & 11 & 10 & 27 & 10 & 9 \\
\hline $\mathrm{La} / \mathrm{Yb}$ & 8.2 & 0.7 & 1.1 & 1.2 & 6.0 & 0.4 & 1.2 \\
\hline
\end{tabular}


Tab. 2 Whole-rock composition of granites of the Bitu-Dzhida Pluton

\begin{tabular}{|c|c|c|c|c|c|c|}
\hline \multirow{2}{*}{$\begin{array}{l}\text { Sample } \\
\text { Phase }\end{array}$} & BD 2417 & BD 2421/1 & BD 3202 & BD 2443 & BD 2438/1 & BD 2414 \\
\hline & \multicolumn{4}{|c|}{ I phase } & \multicolumn{2}{|c|}{ II phase } \\
\hline $\mathrm{SiO}_{2}(\%)$ & 70.53 & 71.14 & 71.60 & 71.68 & 72.32 & 73.51 \\
\hline $\mathrm{TiO}_{2}$ & 0.30 & 0.30 & 0.27 & 0.31 & 0.24 & 0.19 \\
\hline $\mathrm{Al}_{2} \mathrm{O}_{3}$ & 14.47 & 14.93 & 14.99 & 14.76 & 14.04 & 14.15 \\
\hline $\mathrm{Fe}_{2} \mathrm{O}_{3}$ & 0.53 & 0.37 & 2.04 & 0.36 & 0.37 & 0.31 \\
\hline $\mathrm{FeO}$ & 2.73 & 1.87 & 1.15 & 1.81 & 1.90 & 1.59 \\
\hline $\mathrm{MnO}$ & 0.37 & 0.05 & 0.04 & 0.04 & 0.06 & 0.07 \\
\hline $\mathrm{MgO}$ & 0.26 & 0.51 & 0.47 & 0.49 & 0.21 & 0.05 \\
\hline $\mathrm{CaO}$ & 0.59 & 1.97 & 1.56 & 1.86 & 1.11 & 0.72 \\
\hline $\mathrm{Na}_{2} \mathrm{O}$ & 4.10 & 3.99 & 4.34 & 3.76 & 4.00 & 4.18 \\
\hline $\mathrm{K}_{2} \mathrm{O}$ & 3.21 & 3.21 & 3.80 & 3.36 & 4.15 & 4.14 \\
\hline $\mathrm{P}_{2} \mathrm{O}_{5}$ & 0.09 & 0.08 & 0.06 & 0.08 & 0.07 & 0.06 \\
\hline LOI & 2.78 & 1.49 & 0.74 & 1.35 & 1.51 & 1.05 \\
\hline Total & 99.95 & 99.89 & 100.01 & 99.85 & 99.97 & 100.02 \\
\hline Li (ppm) & 328 & 174 & 138 & 140 & 200 & 272 \\
\hline $\mathrm{F}$ & 7000 & 4700 & 2900 & 1900 & 2100 & 5400 \\
\hline $\mathrm{Be}$ & 7.5 & 6.5 & 11.0 & 6.5 & 6.8 & 8.1 \\
\hline $\mathrm{Zn}$ & 366 & 40 & 81 & 24 & 58 & 83 \\
\hline $\mathrm{Ga}$ & 17 & 15 & 23 & 10 & 19 & 21 \\
\hline $\mathrm{Ge}$ & 1.4 & 1.2 & 2.0 & 0.7 & 1.8 & 1.7 \\
\hline $\mathrm{Rb}$ & 296 & 153 & 221 & 83 & 199 & 331 \\
\hline $\mathrm{Sr}$ & 102 & 212 & 188 & 143 & 131 & 103 \\
\hline Y & 14 & 11 & 23 & 9 & 35 & 60 \\
\hline $\mathrm{Zr}$ & 132 & 143 & 177 & 90 & 164 & 162 \\
\hline $\mathrm{Nb}$ & 18 & 14 & 35 & 9 & 39 & 46 \\
\hline $\mathrm{Sn}$ & 25 & 8 & 13 & 3 & 8 & 18 \\
\hline Cs & 12.0 & 8.2 & 13.4 & 3.6 & 9.9 & 11.0 \\
\hline $\mathrm{Ba}$ & 595 & 703 & 685 & 491 & 449 & 361 \\
\hline $\mathrm{La}$ & 23.49 & 24.68 & 25.66 & 17.83 & 34.96 & 36.41 \\
\hline $\mathrm{Ce}$ & 46.01 & 46.43 & 55.77 & 33.75 & 68.80 & 72.18 \\
\hline $\operatorname{Pr}$ & 5.00 & 4.87 & 5.82 & 3.75 & 7.90 & 8.42 \\
\hline $\mathrm{Nd}$ & 17.85 & 18.88 & 21.79 & 12.96 & 29.00 & 37.24 \\
\hline $\mathrm{Sm}$ & 3.89 & 3.23 & 4.42 & 2.61 & 6.99 & 8.32 \\
\hline $\mathrm{Eu}$ & 0.50 & 0.67 & 0.61 & 0.49 & 0.63 & 0.50 \\
\hline $\mathrm{Gd}$ & 2.72 & 2.48 & 4.46 & 1.99 & 6.40 & 8.49 \\
\hline $\mathrm{Tb}$ & 0.40 & 0.32 & 0.68 & 0.28 & 1.15 & 1.46 \\
\hline Dy & 2.36 & 1.91 & 4.04 & 1.56 & 7.05 & 9.38 \\
\hline Но & 0.45 & 0.38 & 0.79 & 0.31 & 1.41 & 1.98 \\
\hline $\mathrm{Er}$ & 1.20 & 1.10 & 2.44 & 0.87 & 3.71 & 5.58 \\
\hline $\mathrm{Tm}$ & 0.18 & 0.16 & 0.39 & 0.13 & 0.56 & 0.86 \\
\hline $\mathrm{Yb}$ & 1.11 & 1.03 & 2.70 & 0.79 & 3.63 & 5.64 \\
\hline $\mathrm{Lu}$ & 0.17 & 0.15 & 0.42 & 0.12 & 0.53 & 0.88 \\
\hline Hf & 4.0 & 4.4 & 7.7 & 2.9 & 5.3 & 7.1 \\
\hline $\mathrm{Ta}$ & 1.2 & 1.6 & 5.5 & 1.2 & 3.3 & 7.7 \\
\hline $\mathrm{Pb}$ & 41.4 & 29.3 & 32.9 & 15.6 & 44.2 & 43.6 \\
\hline Th & 10.9 & 12.2 & 17.8 & 7.7 & 24.0 & 25.1 \\
\hline $\mathrm{U}$ & 3.3 & 3.5 & 5.1 & 2.7 & 7.6 & 7.6 \\
\hline $\mathrm{K} / \mathrm{Rb}$ & 90 & 175 & 143 & 337 & 174 & 104 \\
\hline $\mathrm{Zr} / \mathrm{Hf}$ & 33 & 33 & 23 & 31 & 31 & 23 \\
\hline $\mathrm{La} / \mathrm{Yb}$ & 21.2 & 24.0 & 9.5 & 22.6 & 9.6 & 6.5 \\
\hline
\end{tabular}

\subsection{Bitu-Dzhida Pluton}

The rocks of all three intrusive phases of the Bitu-Dzhida Pluton are also classed as peraluminous granites (Fig. $7 \mathrm{~b}$ ) of the $\mathrm{Li}-\mathrm{F}$ geochemical type. Silica, $\mathrm{Al}_{2} \mathrm{O}_{3}$, and $\mathrm{Na}_{2} \mathrm{O}$ contents increased during the formation of the multiphase intrusion. Compared with average composition of the continental crust (Antipin and Perepelov 2011), the granites of all intrusive phases have high $\mathrm{F}, \mathrm{Li}, \mathrm{Sn}$ contents, and the granites of the second and third phases are enriched in $\mathrm{Ta}, \mathrm{Nb}$, and $\mathrm{Rb}$ (Tab. 2). It should be noted that the granites of the early intrusive phase most closely approach the composition of the continental crust, whereas the rocks of the second and third phases show strongly differentiated distribution of many trace elements (Figs 8-9).

It is also important that the schists of the Bitu-Dzhida Fm. are similar in composition to the continental crust, except for small positive anomalies at Cs, B, and Li (Antipin and Perepelov 2011). The distribution of trace elements, including REE, in the rare-metal granites of the BituDzhida Pluton is consistent with the model of the fractional crystallization of primary magmas during the formation of granites of the second phase (Figs $6 \mathrm{~b}$ and $7 \mathrm{~b}$ ). The model for genesis of the amazonite-albite granites of the third phase invokes fluid-magma liquid immiscibility in a fluorine-rich melt. Similar to the Kharagul and Urugudei plutons, a characteristic geochemical feature of the Bitu-Dzhida Pluton is a regular decrease in some indicator element ratios, $\mathrm{K} / \mathrm{Rb}, \mathrm{Zr} / \mathrm{Hf}$, and $\mathrm{La} / \mathrm{Yb}$, in the amazonite-albite granites of the final intrusive phases (Tab. 2, Fig. 8).

$\mathrm{Sr}-\mathrm{Nd}-\mathrm{Pb}$ isotopic data were obtained for all granitoids of the Late Paleozoic Bitu-Dzhida Pluton (Antipin and Perepelov 2011) (Tabs 4-5; Figs 11-12). They all yield comparable $\mathrm{Nd}$ model ages $\left(\mathrm{T}_{2 \mathrm{DM}}\right)$ of $\sim 1.0$ to $1.3 \mathrm{Ga}$.

\subsection{Janchivlan Pluton}

Major- and trace-element analyses are shown in Tab. 3. Granites display an increase of silica $\left(72-77\right.$ wt. $\% \mathrm{SiO}_{2}$ ) from porphyritic coarse-grained biotite granite 
to Li mica-albite granites. They have high $\mathrm{SiO}_{2}$ and total alkalies (Fig. 6a). Granites are subaluminous to peraluminous with $\mathrm{A} / \mathrm{CNK}$ values ranging from 1.02 to 1.33 (Fig. 7a). They are all highly evolved, but the three phases show distinct contents of silica. The granites of the first phase have $\sim 72 \mathrm{wt}$. $\% \mathrm{SiO}_{2}$, the second phase has a bimodal distribution of silica with maxima at $70 \%$ and 74 wt. $\% \mathrm{SiO}_{2}$, while the third phase granites typically contain $\sim 75$ wt. $\% \mathrm{SiO}_{2}$.

The first- and second-phase granites of the Janchivlan Pluton have low $\mathrm{CaO}$ but high $\mathrm{Al}_{2} \mathrm{O}_{3}$ and $\mathrm{Fe} / \mathrm{Mg}$, plotting into the high-K or shoshonitic fields (Gerel 1990). Their normative composition suggests minimum water pressure during crystallization of $1-0.5$ kbar. On the $\mathrm{Ab}-$ Or-Qtz diagram, Li-F granites plot near the $\mathrm{Ab}$ corner (Kovalenko 1977; Gerel 1990).

Compared with the granites of the early phases, Li-F granites have lower $\mathrm{CaO}$ and $\mathrm{MgO}$ but higher total alkalies and $\mathrm{Fe} / \mathrm{Mg}$ ratio. They have also lower $\mathrm{Ba}$ and $\mathrm{Sr}$ but higher $\mathrm{Li}, \mathrm{Nb}, \mathrm{Rb}$, $\mathrm{Y}$ and $\mathrm{Ga}$ contents. Chondritenormalized REE patterns are typical of evolved granites with strong negative Eu anomaly and enrichment in HREE for $\mathrm{Li}-\mathrm{F}$ granites (Fig. 8d).

Major and trace elements show smooth trends going from granites of the first phase to those of the third phase. Among the trace elements $\mathrm{Rb}, \mathrm{Ta}, \mathrm{Nb}$ and $\mathrm{Th}$ increase, whereas $\mathrm{Sr}$, $\mathrm{Ti}$ and $\mathrm{Ba}$ decrease. Rare-metal granites are enriched in $\mathrm{Li}, \mathrm{Be}$, $\mathrm{Rb}, \mathrm{Ta}, \mathrm{Sn}, \mathrm{W}$ and $\mathrm{F}$ (Tab. 3).

Granites of the Janchivlan Pluton were emplaced in the marginal part of the Khentei Uplift and presumably had a genetic relation with granodiorite-gran-
Tab. 2 Continued

\begin{tabular}{|c|c|c|c|c|c|c|c|}
\hline Sample & BD 3502 & BD 2437 & BD 2436 & BD 3241 & BD 2427 & BD 2406/1 & BD $2406 / 2$ \\
\hline Phase & & & & III phase & & & \\
\hline $\mathrm{SiO}_{2}(\%)$ & 73.24 & 73.70 & 74.16 & 75.07 & 78.05 & 70.37 & 78.02 \\
\hline $\mathrm{TiO}_{2}$ & 0.01 & 0.01 & 0.02 & 0.08 & 0.01 & 0.02 & 0.01 \\
\hline $\mathrm{Al}_{2} \mathrm{O}_{3}$ & 15.63 & 15.46 & 15.08 & 13.14 & 11.58 & 18.59 & 11.65 \\
\hline $\mathrm{Fe}_{2} \mathrm{O}_{3}$ & 1.01 & 0.14 & 0.16 & 1.79 & 0.20 & 0.09 & 0.21 \\
\hline $\mathrm{FeO}$ & 0.57 & 0.69 & 0.80 & 1.22 & 1.03 & 0.47 & 1.06 \\
\hline $\mathrm{MnO}$ & 0.08 & 0.07 & 0.08 & 0.04 & 0.15 & 0.02 & 0.14 \\
\hline $\mathrm{MgO}$ & 0.07 & 0.05 & 0.05 & 0.05 & 0.05 & 0.05 & 0.05 \\
\hline $\mathrm{CaO}$ & 0.04 & 0.05 & 0.07 & 0.30 & 0.05 & 0.08 & 0.08 \\
\hline $\mathrm{Na}_{2} \mathrm{O}$ & 6.74 & 6.00 & 5.85 & 4.35 & 2.53 & 9.57 & 2.64 \\
\hline $\mathrm{K}_{2} \mathrm{O}$ & 2.98 & 3.49 & 3.32 & 4.95 & 5.62 & 0.35 & 5.54 \\
\hline $\mathrm{P}_{2} \mathrm{O}_{5}$ & 0.02 & 0.01 & 0.01 & 0.01 & 0.01 & 0.01 & 0.01 \\
\hline LOI & 0.30 & 0.35 & 0.41 & 0.22 & 0.70 & 0.35 & 0.64 \\
\hline Total & 100.16 & 100.01 & 99.99 & 100.00 & 99.98 & 99.98 & 100.04 \\
\hline Li (ppm) & 492 & 596 & 608 & 87 & 684 & 67 & 1136 \\
\hline $\mathrm{F}$ & 2000 & 3200 & 2800 & 780 & 8800 & 1800 & 9500 \\
\hline $\mathrm{Be}$ & 4.6 & 2.8 & 4.4 & 5.5 & 4.0 & 1.8 & 4.5 \\
\hline $\mathrm{Zn}$ & 272 & 72 & 84 & 123 & 154 & 94 & 304 \\
\hline $\mathrm{Ga}$ & 53 & 37 & 39 & 27 & 16 & 50 & 36 \\
\hline $\mathrm{Ge}$ & 3.6 & 2.8 & 2.8 & 1.8 & 1.1 & 3.5 & 3.4 \\
\hline $\mathrm{Rb}$ & 562 & 532 & 573 & 241 & 725 & 55 & 816 \\
\hline $\mathrm{Sr}$ & 2.2 & 4.2 & 5.0 & 2.5 & 3.0 & 3.2 & 3.2 \\
\hline Y & 16 & 6 & 6 & 11 & 13 & 2 & 26 \\
\hline $\mathrm{Zr}$ & 275 & 216 & 213 & 292 & 86 & 239 & 84 \\
\hline $\mathrm{Nb}$ & 63 & 113 & 350 & 66 & 192 & 21 & 451 \\
\hline Sn & 21 & 21 & 114 & 4 & 49 & 10 & 105 \\
\hline Cs & 16.2 & 7.3 & 7.8 & 5.6 & 3.9 & 2.5 & 14.4 \\
\hline $\mathrm{Ba}$ & 54 & 11 & 15 & 76 & 10 & 11 & 11 \\
\hline $\mathrm{La}$ & 2.81 & 1.43 & 0.56 & 6.48 & 2.11 & 0.23 & 5.37 \\
\hline $\mathrm{Ce}$ & 12.46 & 5.58 & 2.54 & 17.22 & 7.33 & 1.31 & 24.03 \\
\hline $\operatorname{Pr}$ & 1.85 & 0.77 & 0.37 & 2.20 & 1.17 & 0.25 & 3.44 \\
\hline $\mathrm{Nd}$ & 6.80 & 2.61 & 1.22 & 8.71 & 3.40 & 0.81 & 10.52 \\
\hline $\mathrm{Sm}$ & 2.72 & 0.98 & 0.56 & 2.15 & 1.12 & 0.42 & 4.37 \\
\hline $\mathrm{Eu}$ & 0.01 & 0.01 & 0.01 & 0.14 & 0.01 & 0.00 & 0.02 \\
\hline Gd & 2.49 & 0.66 & 0.46 & 2.13 & 0.96 & 0.31 & 4.48 \\
\hline $\mathrm{Tb}$ & 0.72 & 0.19 & 0.17 & 0.43 & 0.32 & 0.10 & 1.19 \\
\hline Dy & 5.93 & 1.64 & 1.62 & 3.11 & 2.42 & 0.84 & 9.42 \\
\hline Но & 1.28 & 0.37 & 0.42 & 0.70 & 0.52 & 0.20 & 2.07 \\
\hline $\mathrm{Er}$ & 5.07 & 1.34 & 1.45 & 2.47 & 2.11 & 0.79 & 7.48 \\
\hline $\mathrm{Tm}$ & 1.08 & 0.27 & 0.32 & 0.44 & 0.48 & 0.15 & 1.56 \\
\hline $\mathrm{Yb}$ & 9.22 & 2.31 & 2.86 & 3.46 & 3.98 & 1.57 & 12.04 \\
\hline $\mathrm{Lu}$ & 1.45 & 0.35 & 0.45 & 0.52 & 0.60 & 0.30 & 1.77 \\
\hline $\mathrm{Hf}$ & 21.2 & 10.3 & 12.5 & 11.5 & 4.2 & 12.2 & 8.7 \\
\hline $\mathrm{Ta}$ & 8.8 & 9.9 & 31.1 & 5.8 & 11.8 & 4.3 & 41.7 \\
\hline $\mathrm{Pb}$ & 69.1 & 37.1 & 57.1 & 40.1 & 41.7 & 44.4 & 110.9 \\
\hline Th & 50.4 & 30.3 & 41.2 & 19.5 & 39.3 & 42.6 & 91.4 \\
\hline $\mathrm{U}$ & 11.3 & 9.7 & 8.7 & 7.2 & 2.9 & 16.6 & 36.5 \\
\hline $\mathrm{K} / \mathrm{Rb}$ & 44 & 55 & 48 & 171 & 65 & 53 & 57 \\
\hline $\mathrm{Zr} / \mathrm{Hf}$ & 13 & 21 & 17 & 25 & 20 & 20 & 10 \\
\hline $\mathrm{La} / \mathrm{Yb}$ & 0.3 & 0.6 & 0.2 & 1.9 & 0.5 & 0.1 & 0.4 \\
\hline
\end{tabular}



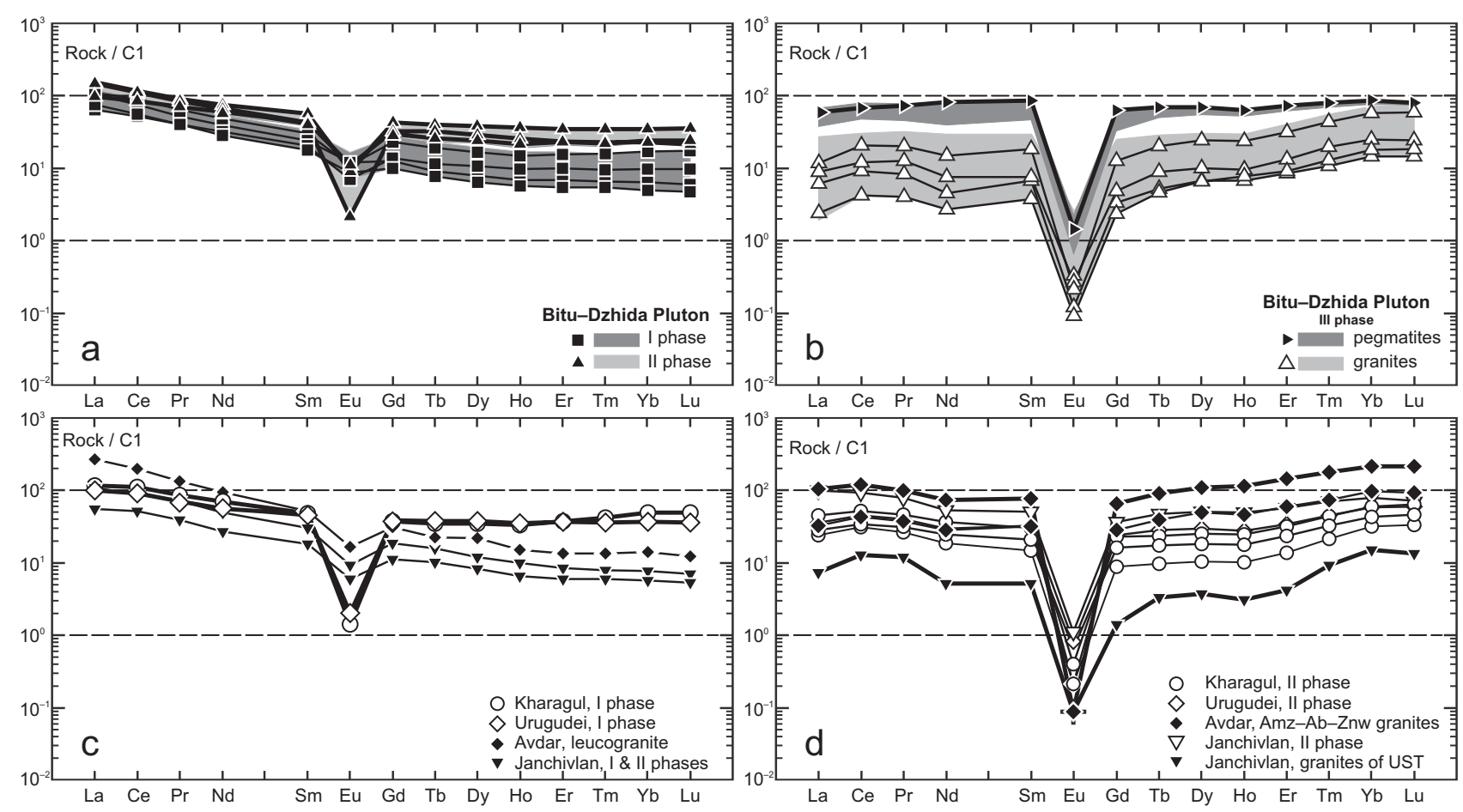

Fig. 8 Chondrite CI normalized (Sun and McDonough 1989) REE patterns in the granites of Central Mongolia and Baikal region.

ite batholiths (Koval 1998). The initial ${ }^{87} \mathrm{Sr} /{ }^{86} \mathrm{Sr}$ ratios range from 0.7049 to 0.7044 for first and second phases, and from 0.7187 to 0.7306 for third-phase granites (Kovalenko et al. 1999). Albite-lepidolite granites show high initial ${ }^{87} \mathrm{Sr} /{ }^{86} \mathrm{Sr}$ ratios due the error associated with high $\mathrm{Rb} / \mathrm{Sr}$ ratios and influence of postmagmatic processes. The $\mathrm{Li}-\mathrm{F}$ granites have very variable initial ${ }^{87} \mathrm{Sr} /{ }^{/ 66} \mathrm{Sr}$. Their Y/
$\mathrm{Nb}$ ratios range between 1.2 and 7.0, and are thus characteristic of $\mathrm{A}_{2}$-type granites (Gerel et al. 1999).

\subsection{The Avdar intrusion}

On classification diagram (Fig. 6a) rocks of the Janchivlan Pluton and Avdar rare-metal intrusion show broad

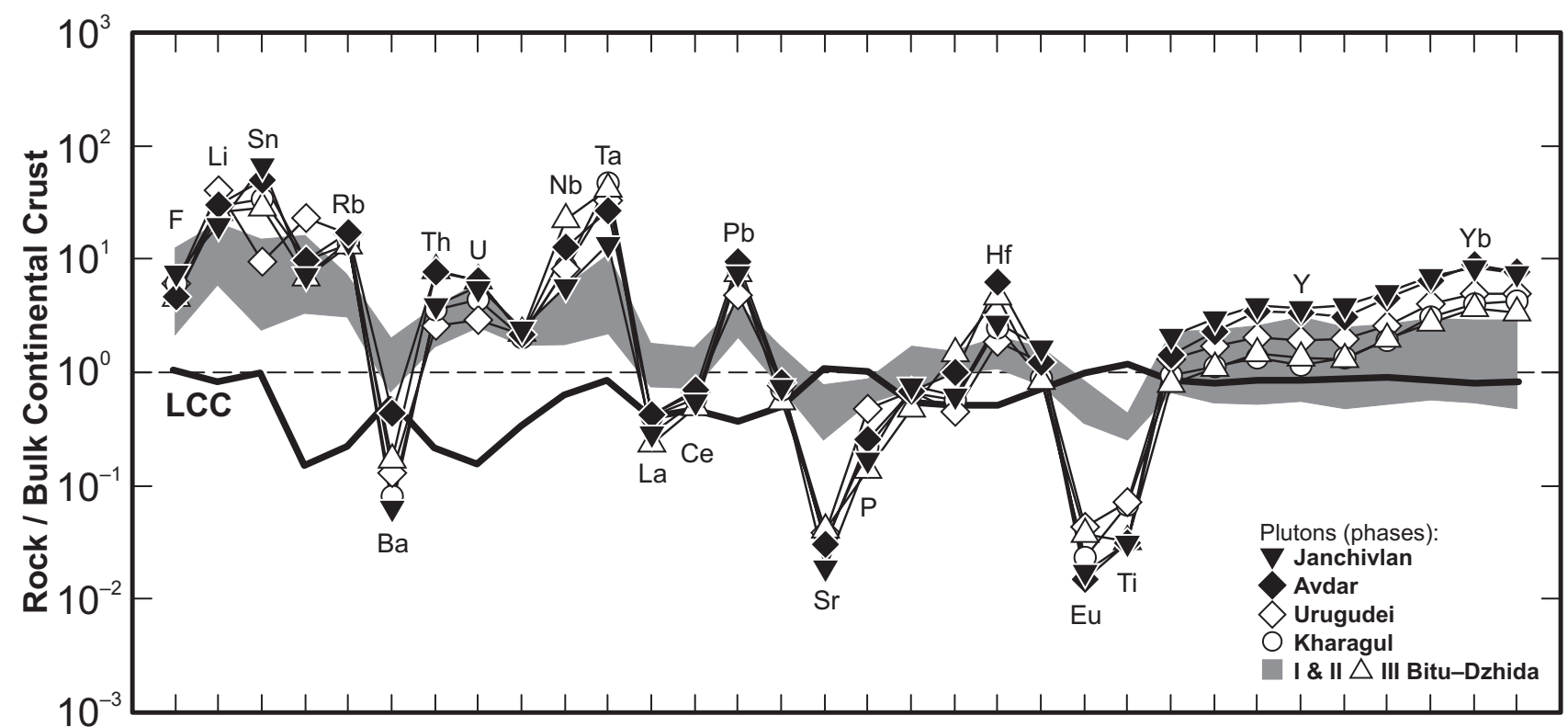

F Li Sn CsRb Ba Th U K Nb Ta La Ce Pb Pr Sr P Nd Zr Hf SmEu Ti GdTb Dy Y Ho Er Tm Yb Lu

Fig. 9 Distribution of average trace-element contents in individual Li-F amazonite-albite granites of Baikal region and Central Mongolia. Normalized to the Bulk continental crust (Rudnick and Gao 2003). 
variation in alkalinity from subalkaline to alkaline granites. The Early Mesozoic granite plutons have very variable potassium and sodium contents. However, most of these raremetal granites have the ratio of $\mathrm{K}_{2} \mathrm{O} / \mathrm{Na}_{2} \mathrm{O}$ close to 1 . On the Shand diagram (Fig. 7a), granites of the Avdar Pluton fall in several fields according to their alkali and alumina balance.

The Avdar and Khoshutul plutons and comagmatic dike belt form a single AvdarKhoshutul intrusive-dike rock series in the peripheral zone of the Early Mesozoic magmatism in the western part of Mongolia in the Mongol-Okhotsk Belt. The Avdar-Khoshutul intrusivedike series is represented by different composition rocks from the early Khoshutul granitoid Pluton $(224 \pm 10 \mathrm{Ma})$ through alkaline syenite intrusions and numerous small subvolcanic dikes of granite-porphyry, and felsic ongonites to late raremetal granites of the Avdar Pluton (209-212 Ma). In the dike belt near the Tsoh ul, dike of ongonite with topaz and fluorite was firstly found, and has the typical petrographic characteristics of these rare-metal subvolcanic rocks (Odgerel and Antipin 2009).

The Li-F granites of the final stage in the Avdar Pluton are typical crustal rocks with high initial ${ }^{87} \mathrm{Sr} /{ }^{86} \mathrm{Sr}$ ratios $(0.84-0.87)$, low initial $\varepsilon_{\mathrm{Nd}}$ values $(+1.2)$ and the $\mathrm{Nd}$ crustal residence $\mathrm{T}_{\mathrm{DM} 2}$ age of $0.9 \mathrm{Ga}$ (Kovalenko et al. 1999).

\section{Mineralization related to rare-metal granites}

Tab. 3 Whole-rock composition of granites of the Janchivlan and Avdar plutons

\begin{tabular}{|c|c|c|c|c|c|c|c|c|}
\hline \multirow{3}{*}{$\begin{array}{l}\text { Sample } \\
\text { Plutons } \\
\text { Phase }\end{array}$} & J 1 & $\mathrm{~J} 2$ & J 4 & J 4479 & A $03-44$ & A 3260 & A $3267 B$ & A $3267 \mathrm{~A}$ \\
\hline & \multicolumn{4}{|c|}{ Janchivlan } & \multicolumn{4}{|c|}{ Avdar } \\
\hline & I phase & II phase & \multicolumn{2}{|c|}{ III phase } & I type & \multicolumn{3}{|c|}{ II type } \\
\hline $\mathrm{SiO}_{2}(\%)$ & 70.60 & 72.44 & 77.23 & 75.99 & 73.62 & 75.96 & 76.00 & 76.64 \\
\hline $\mathrm{TiO}_{2}$ & 0.27 & 0.24 & 0.08 & 0.02 & 0.20 & 0.02 & 0.01 & 0.02 \\
\hline $\mathrm{Al}_{2} \mathrm{O}_{3}$ & 15.11 & 14.46 & 12.50 & 13.03 & 13.65 & 13.75 & 13.32 & 13.58 \\
\hline $\mathrm{Fe}_{2} \mathrm{O}_{3}$ & 0.57 & 0.13 & 0.24 & 0.27 & 1.39 & 0.86 & 0.70 & 0.87 \\
\hline $\mathrm{FeO}$ & 1.40 & 1.33 & 0.93 & 0.79 & 0.55 & 0.65 & 0.50 & 0.50 \\
\hline $\mathrm{MnO}$ & 0.05 & 0.06 & 0.03 & 0.03 & 0.04 & 0.02 & 0.02 & 0.02 \\
\hline $\mathrm{MgO}$ & 0.32 & 0.63 & 0.04 & 0.19 & 0.30 & $<0.050$ & $<0.050$ & $<0.050$ \\
\hline $\mathrm{CaO}$ & 0.91 & 1.21 & 0.38 & 0.26 & 0.90 & 0.25 & 0.23 & 0.27 \\
\hline $\mathrm{Na}_{2} \mathrm{O}$ & 3.61 & 3.55 & 3.88 & 4.32 & 4.12 & 5.31 & 2.86 & 4.86 \\
\hline $\mathrm{K}_{2} \mathrm{O}$ & 5.96 & 4.54 & 4.50 & 4.39 & 4.60 & 3.52 & 6.60 & 3.54 \\
\hline $\mathrm{P}_{2} \mathrm{O}_{5}$ & 0.12 & 0.08 & 0.02 & 0.02 & 0.07 & 0.01 & 0.01 & 0.01 \\
\hline LOI & 0.87 & 0.62 & 1.98 & 0.61 & 0.36 & 0.30 & 0.26 & 0.28 \\
\hline Total & 99.79 & 99.29 & 101.81 & 99.91 & 99.80 & 100.04 & 100.06 & 100.11 \\
\hline $\mathrm{Li}(\mathrm{ppm})$ & 135 & 148 & 400 & 318 & 40 & 358 & 449 & 570 \\
\hline $\mathrm{F}$ & & & & 4100 & 900 & 2600 & & \\
\hline $\mathrm{Be}$ & & & & 6.7 & 1.7 & 21.3 & 8.4 & 8.0 \\
\hline $\mathrm{Zn}$ & & & & 366 & 16 & 177 & 250 & 277 \\
\hline $\mathrm{Ga}$ & 21 & 20 & 29 & 41 & & 48 & 43 & 46 \\
\hline $\mathrm{Ge}$ & & & & 3.6 & & 5.2 & 6.3 & 6.1 \\
\hline $\mathrm{Rb}$ & 377 & 315 & 870 & 701 & 160 & 1110 & 1986 & 1155 \\
\hline $\mathrm{Sr}$ & 127 & 108 & 11 & 6 & 219 & 4 & 3 & 19 \\
\hline $\mathrm{Y}$ & 30 & 14 & 113 & 47 & 22 & 66 & 33 & 57 \\
\hline $\mathrm{Zr}$ & 165 & 105 & 155 & 83 & 298 & 183 & 70 & 157 \\
\hline $\mathrm{Nb}$ & 15 & 11 & 46 & 46 & 23 & 66 & 161 & 132 \\
\hline $\mathrm{Sn}$ & & & & 115 & 3 & 24 & 215 & 217 \\
\hline $\mathrm{Cs}$ & & & & 14.0 & 3.0 & 10.5 & 24.6 & 21.8 \\
\hline $\mathrm{Ba}$ & 500 & 303 & 97 & 30 & 648 & 11 & 11 & 763 \\
\hline $\mathrm{La}$ & 25.53 & 12.94 & 35.48 & 5.67 & 62.89 & 8.26 & 6.01 & 7.70 \\
\hline $\mathrm{Ce}$ & 53.64 & 31.30 & 80.04 & 24.02 & 121.11 & 29.28 & 17.94 & 24.86 \\
\hline $\operatorname{Pr}$ & 6.61 & 3.59 & 9.66 & 3.67 & 12.38 & 3.23 & 2.35 & 3.51 \\
\hline $\mathrm{Nd}$ & 22.22 & 12.24 & 30.23 & 15.46 & 43.22 & 13.75 & 7.18 & 10.83 \\
\hline $\mathrm{Sm}$ & 4.42 & 2.70 & 7.26 & 6.51 & 7.58 & 4.21 & 2.50 & 3.77 \\
\hline $\mathrm{Eu}$ & 0.52 & 0.34 & 0.13 & 0.02 & 0.92 & 0.01 & 0.00 & 0.01 \\
\hline $\mathrm{Gd}$ & 3.66 & 2.18 & 7.09 & 7.65 & 6.11 & 4.82 & 2.93 & 4.18 \\
\hline $\mathrm{Tb}$ & 0.57 & 0.36 & 1.65 & 1.80 & 0.81 & 0.91 & 0.59 & 0.91 \\
\hline Dy & 2.94 & 2.02 & 11.97 & 14.02 & 5.33 & 7.74 & 5.15 & 8.32 \\
\hline Ho & 0.54 & 0.36 & 2.77 & 2.97 & 0.81 & 1.62 & 1.10 & 1.76 \\
\hline Er & 1.34 & 0.94 & 9.33 & 10.68 & 2.13 & 6.75 & 4.58 & 7.55 \\
\hline $\mathrm{Tm}$ & 0.20 & 0.15 & 1.79 & 2.00 & 0.33 & 1.31 & 0.92 & 1.48 \\
\hline $\mathrm{Yb}$ & 1.24 & 0.92 & 12.79 & 15.97 & 2.24 & 12.36 & 8.31 & 13.60 \\
\hline $\mathrm{Lu}$ & 0.17 & 0.13 & 1.80 & 2.26 & 0.30 & 1.86 & 1.21 & 2.04 \\
\hline $\mathrm{Hf}$ & & & & 9.5 & 8.3 & 22.4 & 9.3 & 22.3 \\
\hline $\mathrm{Ta}$ & & & & 9.6 & 2.0 & 17.1 & 23.2 & 23.1 \\
\hline $\mathrm{Pb}$ & 25.0 & 44.0 & 54.0 & 85.0 & 22.0 & 104.4 & 316.5 & 174.3 \\
\hline $\mathrm{Th}$ & & & & 22.1 & 38.4 & 36.4 & 19.3 & 28.0 \\
\hline $\mathrm{U}$ & & & & 7.6 & 2.7 & 5.1 & 10.5 & 11.0 \\
\hline $\mathrm{K} / \mathrm{Rb}$ & 132 & 120 & 43 & 52 & 240 & 26 & 28 & 26 \\
\hline $\mathrm{Zr} / \mathrm{Hf}$ & & & & 9 & 36 & 8 & 8 & 7 \\
\hline $\mathrm{La} / \mathrm{Yb}$ & 20.6 & 14.1 & 2.8 & 0.4 & 28.1 & 0.7 & 0.7 & 0.6 \\
\hline
\end{tabular}

The intrusive-dike complex of the Khamar-Daban Range in the area of the Kharagul and Urugudei plutons, as well as Utulik dike belts with elvans, ongonites, topazites, contains Sn and W veinlet-disseminated zones of the 
Tab. $4 \mathrm{Sr}$ and Nd isotopic compositions of the granites of the Bitu-Dzhida Pluton

\begin{tabular}{lccccccccccccc}
\hline Sample & Phase & $\mathrm{Rb}$ & \multicolumn{1}{c}{$\mathrm{Sr}$} & ${ }^{87} \mathrm{Sr} /{ }^{86} \mathrm{Sr}$ & $2 \sigma$ & ${ }^{87} \mathrm{Sr} /{ }^{86} \mathrm{Sr}(\mathrm{i})$ & $\mathrm{Sm}$ & $\mathrm{Nd}$ & ${ }^{143} \mathrm{Nd} /{ }^{144} \mathrm{Nd}$ & $2 \sigma$ & ${ }^{143} \mathrm{Nd} /{ }^{144} \mathrm{Nd}(\mathrm{i})$ & ${ }^{\varepsilon N d}(\mathrm{i})$ & $\mathrm{T}{ }_{2 \mathrm{DM}}(\mathrm{Ma})$ \\
\hline BD 2417 & I & 296 & 102 & 0.742476 & 13 & 0.705187 & 3.89 & 17.85 & 0.512546 & 31 & 0.512280 & 0.80 \\
BD 2421/1 & I & 153 & 213 & 0.714462 & 10 & 0.705217 & 3.23 & 18.88 & 0.512398 & 7 & 0.512189 & -0.97 & 1022 \\
BD 3202 & I & 221 & 188 & 0.720624 & 2 & 0.705497 & 4.42 & 21.79 & 0.512492 & 5 & 0.512244 & 0.10 & 1169 \\
BD 2414 & II & 331 & 103 & 0.747114 & 17 & 0.705785 & 8.32 & 37.24 & 0.512383 & 6 & 0.512110 & -2.50 & 1297 \\
BD 2438/1 & II & 199 & 131 & 0.724982 & 11 & 0.705526 & 6.99 & 29.00 & 0.512560 & 20 & 0.512266 & 0.52 & 1045 \\
BD 2437 & III & - & - & - & - & - & 0.98 & 2.61 & 0.512543 & 13 & 0.512082 & -3.05 & 1343 \\
BD 3241 & III & - & - & - & - & - & 2.15 & 8.71 & 0.512378 & 8 & 0.512076 & -3.17 & 1352 \\
BD 3502 & III & - & - & - & - & - & 2.72 & 6.80 & 0.512555 & 21 & 0.512066 & -3.38 & 1370 \\
BD 2406/2 & III & - & - & - & - & - & 4.37 & 10.52 & 0.512576 & 7 & 0.512069 & -3.32 & 1365 \\
\hline
\end{tabular}

${ }^{87} \mathrm{Sr} /{ }^{86} \mathrm{Sr}$ and ${ }^{143} \mathrm{Nd} /{ }^{144} \mathrm{Nd}$ values are measured isotopic ratios; ${ }^{87} \mathrm{Sr} /{ }^{86} \mathrm{Sr}(\mathrm{i}),{ }^{143} \mathrm{Nd} /{ }^{144} \mathrm{Nd}(\mathrm{i})$ and $\varepsilon \mathrm{Nd}(\mathrm{i})$ time-corrected values (assumed age $310 \mathrm{Ma}$ ); the $\varepsilon N d$ values were calculated using ${ }^{147} \mathrm{Sm} /{ }^{144} \mathrm{Nd}=0.1967$ and ${ }^{143} \mathrm{Nd} /{ }^{144} \mathrm{Nd}=0.512638$ for the present-day Chondrite Uniform Reservoir (CHUR) (Faure 1986). Nd model ages (Ma) were calculated based on a two-stage model ( $\mathrm{T}_{2 \mathrm{DM}}$ ) of Keto and Jacobsen (1987). Nd model ages $\mathrm{T}_{2 \mathrm{DM}}$ accepted only for samples with ${ }^{147} \mathrm{Sm} /{ }^{144} \mathrm{Nd}<0.14$. All in-run errors of isotopic ratios $(2 \sigma)$ correspond to the last decimal of the reported ratios. The contents $\mathrm{Rb}, \mathrm{Sr}, \mathrm{Sm}$ and $\mathrm{Nd}$ are given in ppm (ICP-MS).

stockwork type, veins, and mineralized breccias. The early veins with $\mathrm{Sn}-\mathrm{W}$ mineralization and mineralized breccias in the stockwork zone contain topaz, fluorite, and tourmaline. The late mineralization is rather uncommon and represented by quartz-feldspar-topaz-cryolite veins with disseminated cassiterite and wolframite (Chernov et al. 1988). Tantalum and tin occurrences in the Kharagul granites were found in separate zones with high tantalite-columbite and cassiterite contents. Tantalum and tin mineralization was also described from pegmatoid veins accompanying the intrusive complex of rare-metal granites.

Miarolitic pegmatites, $\mathrm{Sn}-\mathrm{W}$ veins, $\mathrm{Sn}-\mathrm{W}$ greisens, lepidolite-albite granites and albitites with $\mathrm{Sn}-\mathrm{Ta}-\mathrm{Nb}$ mineralization are known within the Janchivlan Pluton. Miarolitic pegmatites are associated with the phase I porphyritic coarse-grained biotite granites. More than 200 pegmatite bodies are known. They are composed of quartz, microcline, fluorite, topaz, beryl, mica (biotite, muscovite and zinnwaldite), and accessory minerals. A number of $\mathrm{Sn}-\mathrm{W}$ mineralized prospects are associated with the phase II medium-grained muscovite-biotite granites in the Janchivlan Pluton. Ore-bearing veins are small, rarely up to $1 \mathrm{~m}$ thick and $100 \mathrm{~m}$ long. Tourmaline and silica alterations are common. Greisen alteration is characteristic of granites of II and III phases. There are several different types of greisens, but the most common are quartz-tourmaline, quartz-topaz and quartz-muscovite types. Zinnwaldite-bearing greisen (zwitter) was described by Kovalenko et al. (1971).

Tantalum and $\mathrm{Nb}$ mineralization is associated with lepidolite-albite granites and albitites in the Urt Gozgor area. Lepidolite-albite granites stretch along the Ulaandavaa Fault for up to $3.5 \mathrm{~km}$ and are up to $800 \mathrm{~m}$ thick (Fig. 5). These granites have intrusive contacts with the host rocks, and granites of the phases I and III. Series of metasomatic rocks occur in the Urt Gozgor area: lepidolite albitites, amazonite albitites and quartz albitites (albite-lepidolite greisens) (Kovalenko et al. 1971). Albitites consist of albite (90 vol. \%), microcline (3\%), quartz $(3 \%)$, lepidolite $(2.5 \%)$ and topaz $(0.4 \%)$. Lepidolite-albite granites and albitites contain accessory $\mathrm{Ta}-\mathrm{Nb}$ minerals. Unidirectional solidification textures (UST) were recognized in the Urt Gozgor Sn occurrence. The UST are primary magmatic features, formed of parallel to subparallel bands of quartz crystals. These

Tab. $5 \mathrm{~Pb}$ isotopic compositions of granites of the Bitu-Dzhida Pluton

\begin{tabular}{|c|c|c|c|c|c|c|c|c|c|c|c|c|c|}
\hline Sample & Phase & $\mathrm{U}$ & Th & $\mathrm{Pb}$ & ${ }^{206} \mathrm{~Pb} /{ }^{204} \mathrm{~Pb}$ & $2 \sigma$ & ${ }^{207} \mathrm{~Pb} / 204 \mathrm{~Pb}$ & $2 \sigma$ & ${ }^{208} \mathrm{~Pb} / 204 \mathrm{~Pb}$ & $2 \sigma$ & ${ }^{206} \mathrm{~Pb} /{ }^{204} \mathrm{~Pb}(\mathrm{i})$ & ${ }^{207} \mathrm{~Pb} /{ }^{204} \mathrm{~Pb}(\mathrm{i})$ & ${ }^{208} \mathrm{~Pb} / 204 \mathrm{~Pb}(\mathrm{i})$ \\
\hline BD 2417* & I & 3.3 & 10.9 & 41.4 & 18.0711 & 10 & 15.5070 & 10 & 37.8038 & 30 & 17.8280 & 15.4942 & 37.5412 \\
\hline BD 2421/1* & I & 3.5 & 12.2 & 29.3 & 18.2946 & 10 & 15.4960 & 10 & 37.9209 & 30 & 17.9258 & 15.4766 & 37.5037 \\
\hline BD $3202 * *$ & I & 5.1 & 17.8 & 32.9 & 18.5135 & & 15.5238 & & 38.1505 & & 18.0287 & 15.4983 & 37.6054 \\
\hline BD 2414* & II & 7.6 & 25.1 & 43.6 & 18.3407 & 20 & 15.5010 & 20 & 37.9930 & 40 & 17.7982 & 15.4725 & 37.4133 \\
\hline BD 2438/1* & II & 7.6 & 24.0 & 40.2 & 18.3667 & 20 & 15.4820 & 90 & 37.9089 & 40 & 17.7786 & 15.4511 & 37.3097 \\
\hline BD 2437* & III & 9.7 & 30.3 & 37.1 & 18.0063 & 20 & 15.4619 & 20 & 37.8128 & 50 & 17.2023 & 15.4196 & 36.9978 \\
\hline BD $3241 * *$ & III & 7.2 & 19.5 & 40.1 & 17.9818 & & 15.4754 & & 37.9063 & & 17.4280 & 15.4463 & 37.4199 \\
\hline BD $3502 * *$ & III & 11.34 & 50.4 & 69.1 & 18.1724 & & 15.4919 & & 38.0692 & & 17.6626 & 15.4651 & 37.3372 \\
\hline BD 2406/1* & III & 16.6 & 42.6 & 44.4 & 18.6321 & 8 & 15.5084 & 8 & 38.3496 & 20 & 17.4613 & 15.4469 & 37.3760 \\
\hline BD $2406 / 2 * *$ & III & 36.5 & 91.4 & 110.9 & 18.4586 & & 15.5044 & & 38.2089 & & 17.4329 & 15.4505 & 37.3770 \\
\hline
\end{tabular}

${ }^{206} \mathrm{~Pb} /{ }^{204} \mathrm{~Pb},{ }^{207} \mathrm{~Pb} / 204 \mathrm{~Pb}$ and ${ }^{208} \mathrm{~Pb} /{ }^{204} \mathrm{~Pb}$ are measured isotopic ratios, $*$ corrected for mass fractionation and $* *$ by dual isotope dilution method; ${ }^{206} \mathrm{~Pb} /{ }^{204} \mathrm{~Pb}(\mathrm{i}),{ }^{207} \mathrm{~Pb} /{ }^{204} \mathrm{~Pb}$ (i) and ${ }^{208} \mathrm{~Pb} /{ }^{204} \mathrm{~Pb}$ (i) are initial (time-corrected) ratios respectively (assumed age $310 \mathrm{Ma}$ ). All in-run errors of isotopic ratios $(2 \sigma)$ correspond to the last decimal of the reported ratios. The contents of $\mathrm{U}$, Th and $\mathrm{Pb}$ given in ppm. 
textures were described by Kormilitsyn and Manuylova (1957), Povilaitis (1961), Bakumenko et al. (1981), Shannon et al. (1982) and Kirwin (2005). In general, these structures common in differentiated felsic intrusions in Mongolia are associated with Sn, Mo, porphyry $\mathrm{Cu}-\mathrm{Au}$, intrusion-related $\mathrm{Cu}$ and REE mineralizations, and are considered to be a useful indicator for volatilerich intrusive complexes, at a distinct prospecting scale (Kirwin 2005).

Within the Avdar-Khoshutul intrusive-dike rock series are known occurrences of rare-metal mineralization in the western part of Avdar Pluton. It is Ta-Nb, and Sn-Wcontaining mineralized core and connected with spatial individual placers $(\mathrm{Sn}, \mathrm{W}, \mathrm{Ta}-\mathrm{Nb})$ that may be genetically linked to the granites of the Avdar Pluton.

\section{Discussion}

\subsection{Geotectonic setting and geochemical evolution of studied rare-metal granites}

This study reveals that all Late Paleozoic intrusions of rare-metal granites and accompanying subvolcanic dikes are confined to a single regional structure of the Khamar-Daban Ridge on the periphery of the large area of granitoid magmatism. The almost identical ages of the Kharagul, Urugudei, and Bitu-Dzhida plutons with the petrological and geochemical similarity of their raremetal granites give grounds to assign them to a single geochemical type of Li-F granites and assume similar conditions of their formation.

The intraplate Late Paleozoic rare-metal granitic magmatism of the Khamar-Daban Ridge area shows a progressive increase in $\mathrm{Na}_{2} \mathrm{O}, \mathrm{F}, \mathrm{Li}, \mathrm{Rb}, \mathrm{Cs}, \mathrm{Sn}, \mathrm{Be}, \mathrm{Ta}$ and $\mathrm{Pb}$ and a simultaneous decrease in $\mathrm{FeOt}, \mathrm{CaO}, \mathrm{K}_{2} \mathrm{O}$, $\mathrm{Ba}, \mathrm{Sr}, \mathrm{Zn}, \mathrm{Zr}$, Th and $\mathrm{U}$ contents in the late intrusive phases (Tab. 2). A similar evolution was identified for the subvolcanic rocks, which confirms that both granites and related dikes belong to a single intrusive-dike complex (Antipin et al. 1999).

The Late Paleozoic rare-metal intrusions show broad variations in alkalinity. While the early biotite granites are mostly subalkaline, the rare-metal Li-F granites tend to be more alkaline, and fall at the border or even in the field of alkalic series (Fig. 6).

Early Mesozoic granites were emplaced after the continental collision and closure of the Mongol-Okhotsk Ocean which resulted in voluminous granitic magmatism producing batholiths in the Khentei Uplift's core as well as shallow small plutons outside the MongolOkhotsk Belt (e.g. Zonenshain et al. 1990; Koval 1998; Kovalenko et al. 1999). Yarmolyuk et al (2002) and Yarmolyuk et al. (2013) interpreted the Khentei Batho- lith as a result of mantle plume activity in an intraplate tectonic setting.

Still, the evolutions of diachronous (Late Paleozoic vs. Early Mesozoic) rare-metal granites of the Baikal region and in Central Mongolia show a geochemical similarity (Figs 6-7). It is expressed by an increase in $\mathrm{F}, \mathrm{Li}, \mathrm{Rb}, \mathrm{Cs}$, $\mathrm{Sn}, \mathrm{Be}, \mathrm{Ta}$ and $\mathrm{Pb}$ and a decrease in $\mathrm{Sr}, \mathrm{Ba}, \mathrm{Zn}, \mathrm{Zr}$, Th and $\mathrm{U}$ contents in course of multiphase intrusions formation (Tabs 1-3; Figs 8-9).

On the other hand, there are also marked differences in $\mathrm{K}_{2} \mathrm{O} / \mathrm{Na}_{2} \mathrm{O}$ ratios (wt. \%). This ratio is greatly shifted in favor of $\mathrm{Na}_{2} \mathrm{O}$ for Late Paleozoic rare-metal granites, whereas their Mesozoic counterparts have $\mathrm{K}_{2} \mathrm{O} / \mathrm{Na}_{2} \mathrm{O}$ close to, or greater than, unity. High $\mathrm{Na}$ contents in the Late Paleozoic rare-metal granites should be partly of metasomatic origin.

\subsection{Unidirectional Solidification Textures (UST)}

The magmatic mode of genesis of rare-metal Li-F granites is confirmed not only by geochemical data, but also by the presence of Unidirectional Solidification Textures (UST) in Bitu-Dzida and Urt Gozgor (Janchivlan) late phases. The UST zones are thought to be products of rhythmic precipitation of quartz and quartz + feldspar during periods of volatile over pressure within relatively small degassing felsic cupolas. The formation of UST is considered to be result of pulsating pressure changes across cotectic boundaries in the quartz-feldspar stability field. The quartz stability field expands with increasing pressure (Tuttle and Bowen 1958) and thus alternating bands of quartz and quartz plus feldspar are precipitated in cupolas as the cotectic boundary oscillates during pressure variation (Kirwin 2005).

In the Bitu-Dzhida intrusion were observed also heterogeneous solidification textures of liquid immiscibility (liquation) with segregation into two zones: fine-grained $\mathrm{Ab}-\mathrm{Kfs}$ granite and coarse-grained $\mathrm{Amz}-\mathrm{Ab}-\mathrm{Znw}$ granite (Fig. 10a). The recombined composition of these zones is corresponding to an average composition of massive $\mathrm{Amz}-\mathrm{Ab}-\mathrm{Znw}$ granite of this pluton, as shown on the example of the REE pattern (Fig.10b). This may indicate the parental rare-metal granitic magma later split into ore-bearing and barren phases.

\subsection{Magma source}

Initial $\varepsilon N d$ values ranging from -1.2 to -2.7 and two-stage $\mathrm{Nd}$ model ages $\left(\mathrm{T}_{2 \mathrm{DM}}\right)$ older than $1.2 \mathrm{Ga}$ were previously obtained for the Urugudei-Kharagul group of Late Paleozoic intrusions indicating that these plutons could have formed by melting of the local Precambrian continental crust (Kovalenko et al. 

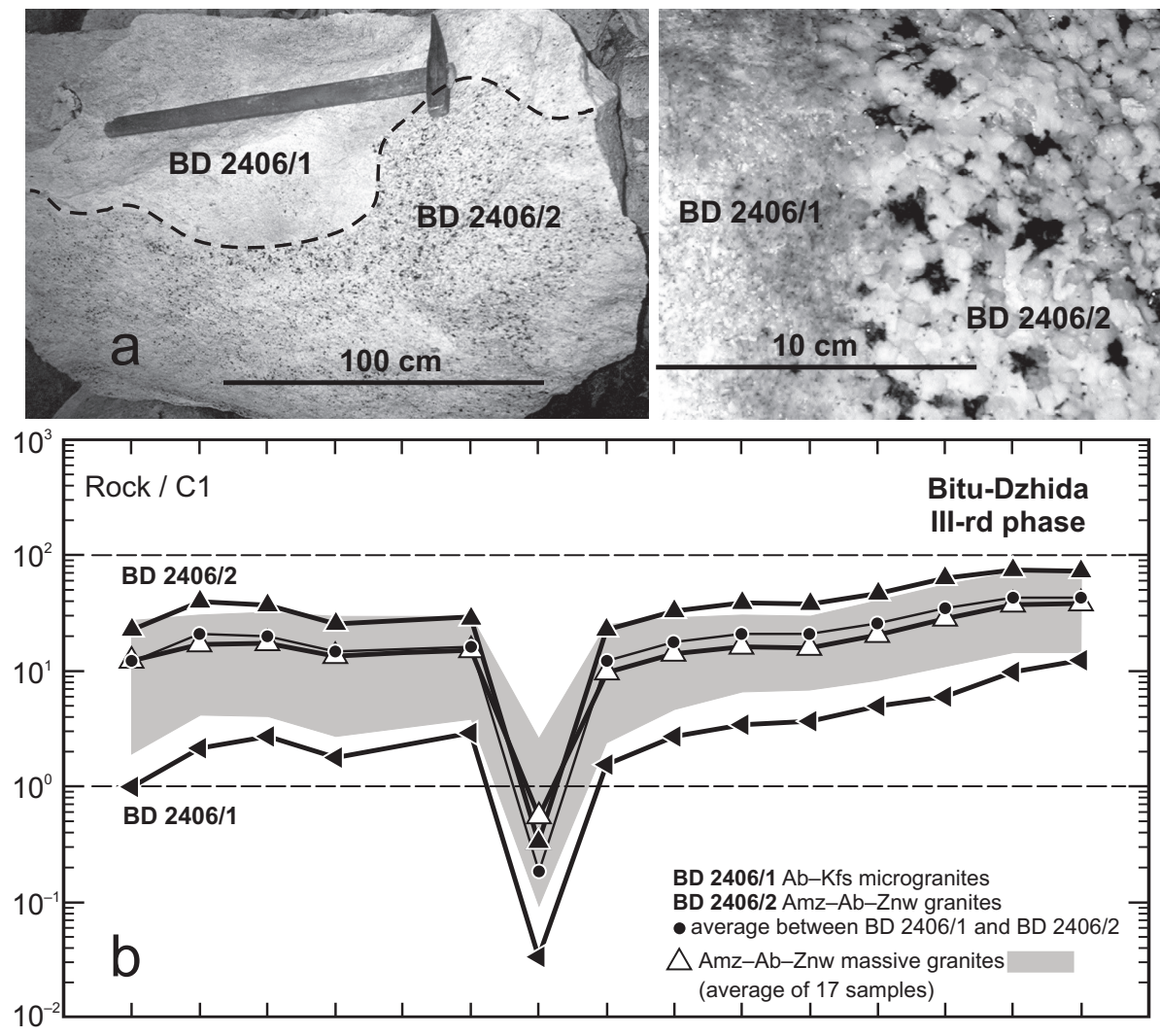

Fig. 10 Heterogeneous solidification texture of the Bitu-Dzhida Pluton. Photo of sample (a) and chondritenormalized (McDonough and Sun 1995) REE pattern (b).
1999). The whole-rock geochemical and isotope compositions point to the southern Baikal Precambrian continental crust as the most likely source (Makrygina 1981). The melting of the Precambrian continental crust of the Khamar-Daban Range could have been

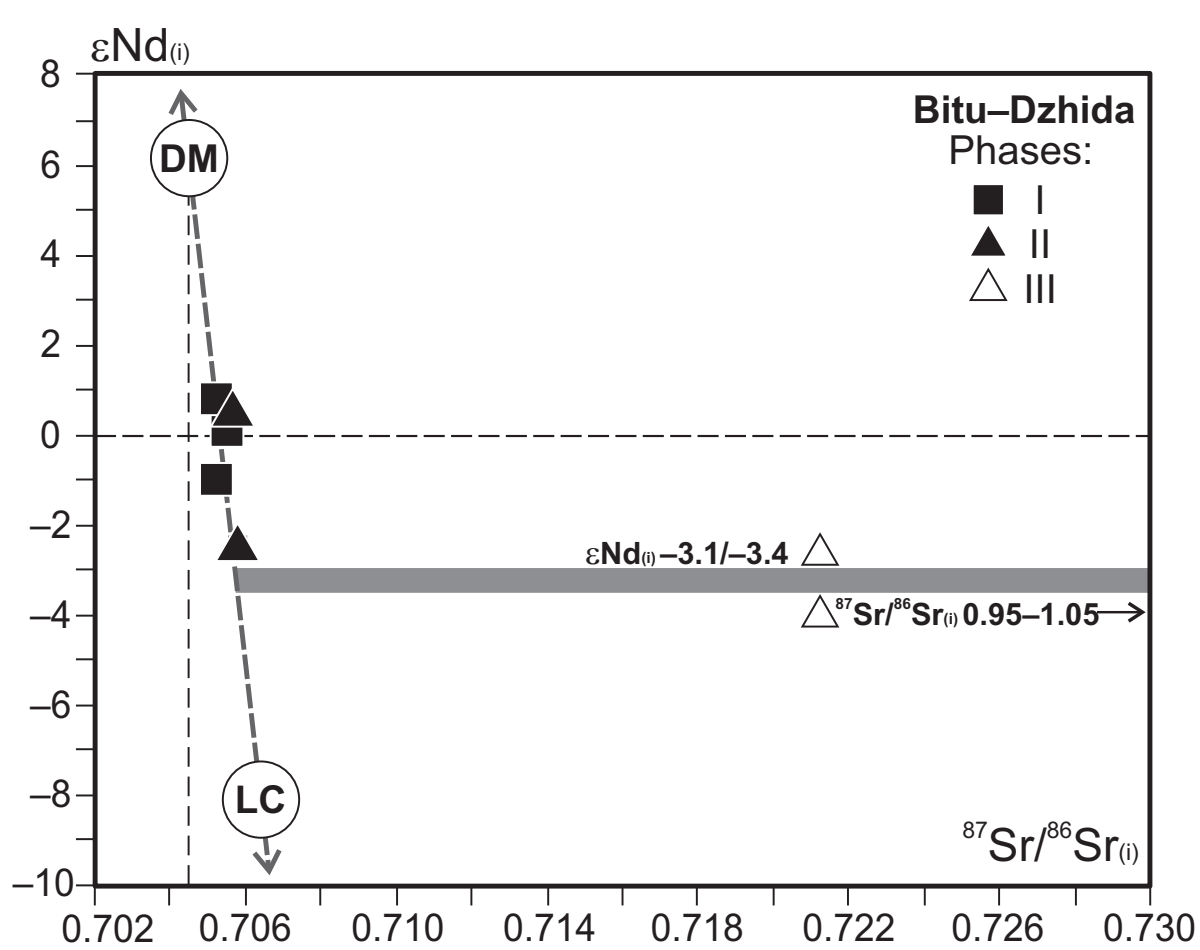

\subsection{Origin of $L i-F$ magma}

Genesis of rare-metal granites is still being discussed. Beus et al (1962) interpreted these granites as metasomatically albitized (apogranites). Magmatic genesis of $\mathrm{Li}-\mathrm{F}$ granites was proposed by Kovalenko et al. (1971) and proved in many world provinces (Haapala 1977; Christansen et al. 1988; Dostal and Chatterjee 1995; Raimbault et al. 1995; Antipin and Perepelov 2011). Origin of the raremetal granite magma enriched in LILE components in both

Fig. $11 \mathrm{Sr}$ and $\mathrm{Nd}$ isotope characteristics of the Bitu-Dzhida granites. DM - Depleted Mantle, LC - Lower Crust (Kovalenko et al. 1999). 
Fig. 12 The whole-rock ${ }^{206} \mathrm{~Pb} /{ }^{204} \mathrm{~Pb}$ vs. ${ }^{207} \mathrm{~Pb} /{ }^{204} \mathrm{~Pb}$ plot for the Bitu-Dzida Pluton. The $\mathrm{Pb}$ evolution curves for the main crustal and mantle reservoirs are after Kramers and Tolstikhin (1997). Lead evolution model for granitoids of the Bitu-Dzhida Pluton was calculated following Stacey and Kramers (1975).

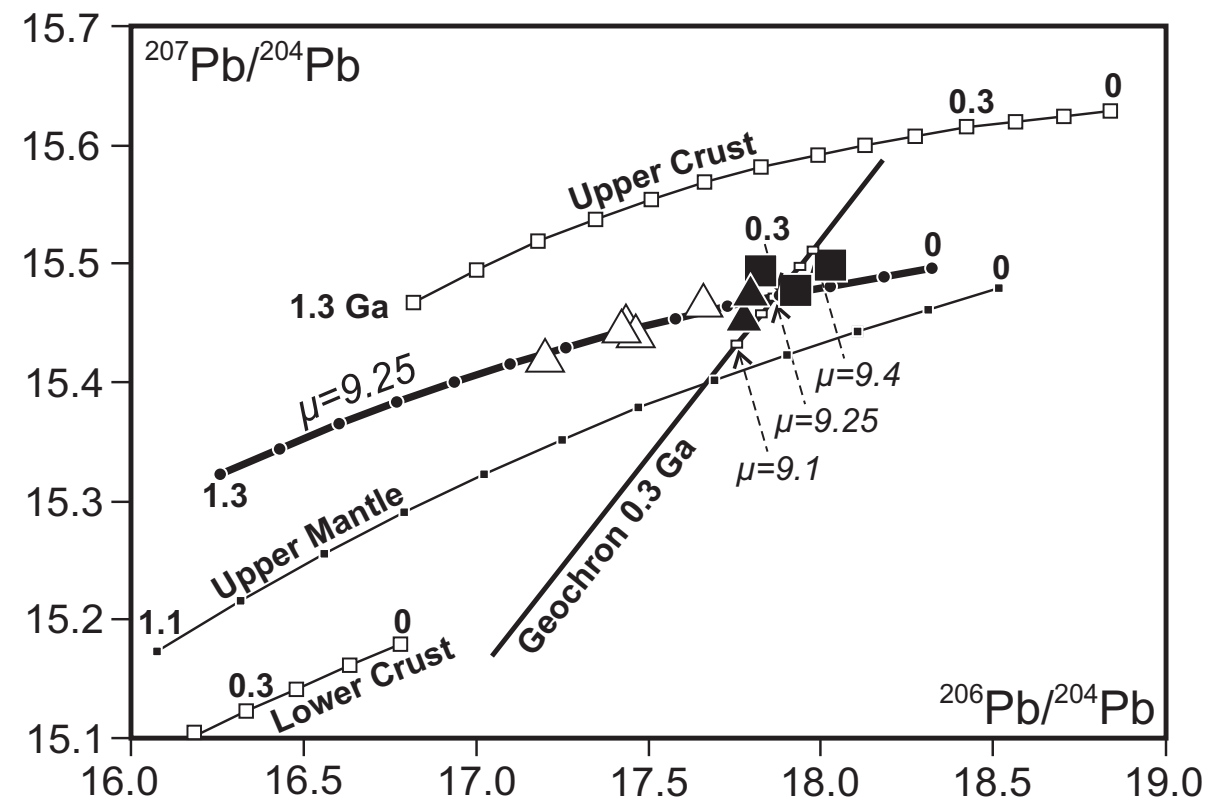

fluid in the granitic melts would consistently increase with decreasing degree of anatectic melting, yielding the most enriched $\mathrm{F}, \mathrm{Li}, \mathrm{Rb}, \mathrm{U}$ and $\mathrm{Th}$ granitic magmas.

Assumed importance of $\mathrm{CO}_{2}$-rich fluid in transfer of trace elements is confirmed by forming of REE-carbonate in the rare metal granites. For example, in the BituDzhida Pluton, the Phase I granites contain accessory mineralization of REE-carbonates (parisite, synchysite) and the Phase III Amz-Ab-Znw granites Fe-Mn-containing calcite.

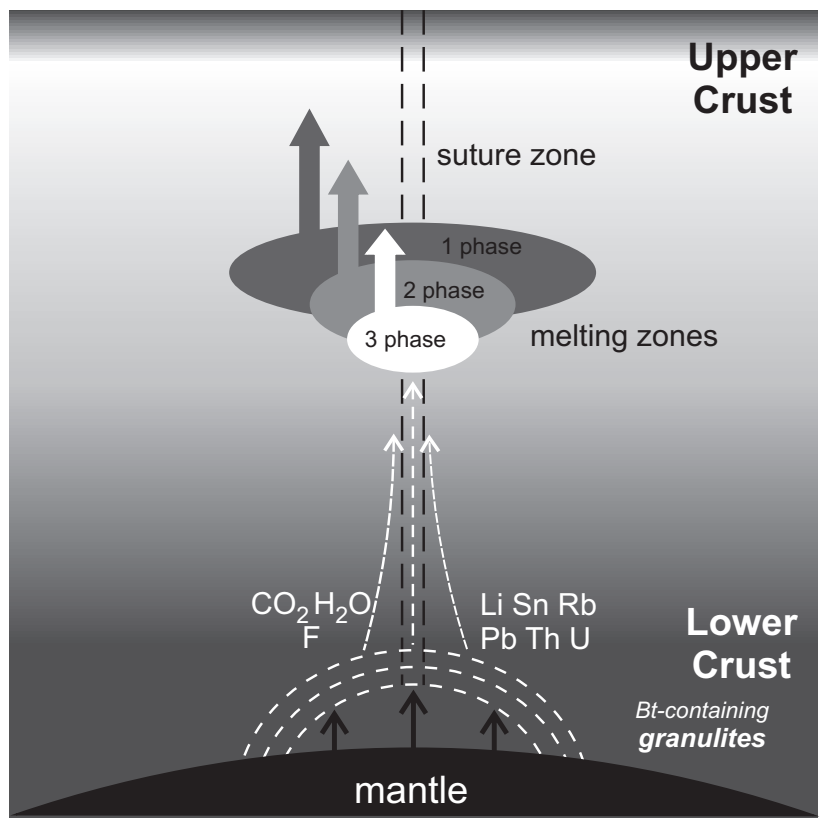

Fig. 13 The conceptual model of the genesis of the rare-metal granitic magma due to the crust-mantle interaction (modified from Cuney and Barbey 2014). 
Lead isotopic characteristics of rare-metal granites in the Bitu-Dzhida Pluton indicate the relatively old lower crust as a source of the LILE-enriched fluids. The most clearly is this shown in the granites of the final phase (Fig. 12), which were formed in the end of anatectic melting and were thus fluid-enriched.

Presence of UST and variation in our geochemical data also support the magmatic genesis of granites from the Janchivlan Pluton. The elevated alkalinity and low initial ${ }^{87} \mathrm{Sr} /{ }^{86} \mathrm{Sr}$ ratios (0.704) for the first- and second-phase granites suggest their deep crustal origin. Low initial ${ }^{87} \mathrm{Sr} /{ }^{86} \mathrm{Sr}$, close to the mantle values, are characteristic of many rare-metal granites (Kostitsyn 2001).

There is a significant increase in $\mathrm{Nb}, \mathrm{Y}$ and $\mathrm{Zr}$ and a decrease in $\mathrm{Ba}$ and $\mathrm{Sr}$ from the first- to the third-phase granites for multiphase plutons like the Janchivlan. This variation could be due to the fractional crystallization, especially the increase of $\mathrm{Rb}$ (the average $\mathrm{K} / \mathrm{Rb}$ ratios rise from 170 for the first phase, through 158 for the second and 63 for the third-phase leucogranites, to 19-13 in $\mathrm{Li}-\mathrm{F}$ granites)

Granites of the third phase are highly fractionated with complex magmatic and metasomatic signature. The source of $\mathrm{F}$ and rare elements was probably magmatic. At the late- magmatic and early postmagmatic stage, there was a new inversion of magmatic fluids. In later phases of the rare-metal intrusions practically exhausted the potential of fractional crystallization, and the microcline-albite facies formed with maximum concentrations of LIL and ore elements. Total REE fall accompanied by an increase in HREE, similar to albitized granite and albitites.

However, the comparative geochemical analysis of the calc-alkaline and $\mathrm{Li}-\mathrm{F}$ granites suggests that the crustal anatexis alone could not have produced magmas with the geochemical characteristics of the rare-metal granites. Clearly, any subsequent fluid-magmatic fractionation would have resulted in extensive enrichment in $\mathrm{F}$ and many trace elements as observed in Li-F granites and their subvolcanic analogues (ongonites), presumed products of the residual magmas crystallization. In the recent study of ongonites, Dostal et al. (2015) have shown that they underwent subsolidus exchange with deuteric fluids which led to the origin of secondary $\mathrm{Li}-\mathrm{Fe}$-rich micas enriched in rare metals.

In any case, the presence of UST shows that the apical parts of the felsic intrusions formed at relatively high temperatures. Indeed, temperatures of $780-800^{\circ} \mathrm{C}$ were obtained based on biotite $\mathrm{Fe} /(\mathrm{Fe}+\mathrm{Mg})$ ratio and fugacity of oxygen $\left(\mathrm{fO}_{2}\right)$ (Wones and Eugster 1965) as well as zircon saturation thermometry (Watson and Harrison 1983) (Gerel 1990). These data are in a good agreement with fluid inclusions study of Koval (1998) for Mesozoic granitoids in the Mongol-Okhotsk Belt yielding $940^{\circ} \mathrm{C}$ for rare-metal granites and $860^{\circ} \mathrm{C}$ for $\mathrm{Li}-\mathrm{F}$ granites, e.g. microcline-albite ones. At these conditions, volatile activity increased and resulted in formation of UST in the relatively closed system. Postmagmatic stage was then responsible for the rare-metal mineralization.

Volatiles are considered to play an important role in the petrogenesis of the Li-F granites. Highly evolved granites with $\mathrm{Li}-\mathrm{F}$ facies have been described from many rare-metal provinces in the world (e.g. Kovalenko et al. 1971; Gerel 1990; Štemprok 1991; Taylor 1992; Dostal and Chatterjee 1995; Raimbault et al. 1995; Reyf et al. 1999; Antipin et al. 2001; Kostitsyn 2001; Linnen and Cuney 2005; Badanina et al. 2010; Gu et al. 2010).

For example, in the Janchivlan Pluton, the F content varies from 0.17 in the first phase, 0.19 in the second, $0.28-0.39$ in the third, and up to $1.03-2.00 \%$ in the ongonites (Kovalenko et al. 1971; Koval 1998). The abundance of $\mathrm{F}$ resulted in a highly mobile magma capable of reaching high crustal levels (Kovalenko 1977).

The Li-F granites always occur in the highest level of leucocratic cupolas or at the inner contacts of multiphase plutons (Kovalenko et al. 1971; Gerel 1990). The presence of late-stage F-rich fluid was also important for the metasomatic processes. The $\mathrm{Li}-\mathrm{F}$ granites were followed by albitites and microclinites, greisens and quartz veins with $\mathrm{Sn}, \mathrm{W}$ and $\mathrm{Ta}-\mathrm{Nb}$ mineralization.

\section{Conclusions}

Late Paleozoic and Early Mesozoic rare-metal granitoids of Central Mongolia and Baikal region form small (up to $10 \mathrm{~km}^{2}$ ) multiphase intrusions, sharing similar modal composition, petrology and whole-rock geochemistry. Their geochemical evolution shows that they belong to a common geochemical type of $\mathrm{Li}-\mathrm{F}$ granites. It is expressed by a progressive increase in $\mathrm{F}, \mathrm{Li}, \mathrm{Rb}, \mathrm{Cs}, \mathrm{Sn}, \mathrm{Be}$, $\mathrm{Ta}, \mathrm{Pb}$ and drop in $\mathrm{Sr}, \mathrm{Ba}, \mathrm{Zn}, \mathrm{Zr}$, Th and $\mathrm{U}$ during the formation of these multiphase intrusions. The geochemical data suggest the magmatic genesis of rare-metal $\mathrm{Li}-\mathrm{F}$ granites, and the process of magma differentiation leading to the formation of topaz-bearing amazonite-albite and lepidolite-albite granites.

In addition, metasomatic albitites, microclinites, zwitter and muscovite greisens are associated with the rare-metal mineralization. Rare-metal $\mathrm{Li}-\mathrm{F}$ granites show a characteristic geochemical signature, independent of their age as well as the composition of their Precambrian and Phanerozoic metasedimentary country rocks. Based on the isotopic and whole-rock geochemical data, the initial generation of rare-metal Li-F magmas could have occurred in the lower continental crust during the granulite-facies metamorphism of biotite-rich metasediments. 
The genetic scenario assumes an influence of mantle diapir on the crustal rocks that underwent the granulitefacies metamorphism at low pressures; an alternative is delamination and sinking into the mantle of lower crustal blocks, both causing destruction of hydroxylbearing minerals. In either case, the $\mathrm{CO}_{2}-\mathrm{H}_{2} \mathrm{O}-\mathrm{F}$-rich fluids would have induced anatectic crustal melting and formation of rare-metal magmas. Later, this magma could have undergone a long and deep magmatic differentiation leading to an enrichment of residual magmas and fluids in lithophile elements and fluorine at the late- and postmagmatic stages.

Rare-metal Li-F granites of studied provinces have intraplate origin and geochemically differ from the Early Paleozoic collisional granitoids. In contrast to the raremetal intrusions, monzodiorites and quartz monzonites form large plutons in the near periphery of the AngaraVitim Batholith and occur in the composite dikes of belt consisting of intrusions and dikes. Rare-metal granites formed on the periphery of the Late Paleozoic and Early Mesozoic magmatic belts, often as a part of intrusivedike complexes.

Acknowledgements. Research has been supported by the RNF grant 15-17-10010. The authors are very grateful to the handling editor K. Schulmann and editor in chief V. Janoušek, as well as two anonymous reviewers for valuable and very constructive comments.

\section{References}

AnTiPIN VS (1977) Petrology and Geochemistry of Granitoids of Various Depth Facies. Nauka, Novosibirsk, pp 1-160 (in Russian)

Antipin VS, Perepelov AB (2011) Late Paleozoic rare-metal granitoid magmatism of the southern Baikal region. Petrology 19: 370-381

Antipin VS, Savina EA, Mitichin MA, Perelyaev Vi (1999) Rare-metal lithium-fluorine granites, ongonites and topazites of the South Baikal region. Petrology 7: 145-155 (in Russian)

Antipin VS, Halls C, Seltmann R (2001) Elvan and ongonite magmas with associated rare-metal mineralization. In: PiestrzyŃski et al. (eds) Mineral Deposits at the Beginning of the $21^{\text {st }}$ Century. Proceedings of the Joint Sixth biennial SGA-SEG Meeting, Kraków, Poland. Balkema, Lisse, pp 359-362

Antipin VS, Halls C, Mitichiin MA, Scot P, Kuznetsov AN (2002) Elvan of Cornwall (England) and southern Siberia as subvolcanic counterparts of subalkalic raremetal granites. Rus Geol Geoph 9: 847-857

Badanina EV, Veksler IV, Thomas R, Syritso LF, TrumBULL RB (2010) Magmatic evolution of Li-F, rare metal granites: a case study of melt inclusions in the Khangilay Complex, Eastern Transbaikalia (Russia). Chem Geol 210: 113-133

Bakumenko LT, Kasukhin ON, Kosals JA, Lkhamsuren J (1981) On the genesis of rhythmically banded textures in granitoids. Dokl Akad Nauk SSSR 260: 444-448 (in Russian)

Beus AA, Severov VA, Citnin AA, Cubbotin KD (1962) Albitizated and Greisenizated Granites (Apogranites). Academy of Sciences of USSR, Moscow, pp 1-196

Chernov BS, Getmanskaya TI, Mednikov NI (1988) On cryolite-tin-tungsten-silver mineralization. Geol Rudn Mestorozhd 1: 69-76

Christiansen EH, Stuckless JS, Funkhouser MJ, Howell KA (1988) Petrogenesis of rare-metal granites from depleted crustal sources - an example from the Cenozoic of western Utah, USA. In: TAYLOR RP, STRONG DF (eds) Recent Advances in the Geology of Granite-Related Mineral Deposits. Canadian Institute of Mining and Metallurgy Special Volume 39: pp 307-325

Collins WJ, Beams SD, White AR, Chappell BW (1982) Nature and origin of A-type granites with particular reference to southeastern Australia. Contrib Mineral Petrol 80: 189-200

Cuney M, Barbey P (2014) Uranium, rare metals, and granulite-facies metamorphism. Geosci Front 5: 729-745

Donskaya TV, Gladkochub DP, Mazukabzov AM, Ivanov AV (2013) Late Paleozoic-Mesozoic subduction-related magmatism at the southern margin of the Siberian Continent and the 150 million-year history of the MongolOkhotsk Ocean. J Asian Earth Sci 62: 79-97

Dostal J, Chatteijee AK (1995) Origin of topaz-bearing and related peraluminous granite of the Late Devonian Davis Lake Pluton, Nova Scotia, Canada: crystal versus fluid fractionation. Chem Geol 123: 67-88

Dostal J, Kontak DJ, Gerel O, Shellnutt JG, Favek M (2015) Cretaceous ongonites (topaz-bearing albite-rich microleucogranites) from Ongon Khairkhan, Central Mongolia: products of extreme magmatic fractionation and pervasive metasomatic fluid: rock interaction. Lithos 236-237: 173-189

FAURE G (1986) Principles of Isotope Geology, $2^{\text {nd }}$ edn. John Wiley and Sons, New York, pp 1-589

Frost BR, Barnes CG, Collins WJ, Arculus RJ, Ellis DJ, Frost CD (2001) A geochemical classification for granite rocks. J Petrol 42: 2033-2048

Galer SJG (1999) Optimal double and triple spiking for high precision lead isotopic measurement. Chem Geol 157: $255-274$

Gerel O (1990) Petrology, Geochemistry and Mineralisation of Mesozoic Subalkaline Granites in Mongolia. Unpublished Doctor of Sciences thesis, Vinogradov Institute of Geochemistry, Irkutsk, pp 1-395 (in Russian) 
Gerel O, Kanisawa S, Ishikawa K (1999) Petrological characteristics of granites from the Avdrant and Janchivlan plutons, Khentei Range, Central Mongolia. Problems of geodynamics and metallogeny of Mongolia. Transactions 13: 34-39

Gu LX, Zhang ZZ, Wu CZ, Gou XQ, LiaO JJ, Yang H (2010) A topaz- and amazonite-bearing leucogranite pluton in eastern Xinjiang, NW China and its zoning. J Asian Earth Sci 42: 885-902

HaApala I (1977) Petrography and geochemistry of the Eyrajoki stock, a rapakivi-granite complex with greisentype mineralization in south-western Finland. Bull Geol Surv Finland 290: 122-133

Jahn BM, Capdevila R, Liu D, Vernov A, Badarch G (2004) Sources of Phanerozoic granitoids in the transect Bayanhongor-Ulan Baator, Mongolia: geochemical and $\mathrm{Nd}$ isotopic evidence, and implications of Phanerozoic crustal growth. J Asian Earth Sci 23: 629-653

Jahn BM, Litvinovsky BA, Zanvilevich AN, Reichov M (2009) Peralkaline granitoid magmatism in the Mongolian-Transbaikalian Belt: evolution, petrogenesis and tectonic significance. Lithos 113: 521-539

Keto LS, JACOBSEN SB (1987) Nd and Sr isotopic variations of Early Paleozoic oceans. Earth Planet Sci Lett 84: 27-41

KiMURA JI, TAKAKU Y, YoshidA T (1995) Igneous rock analysis using ICP-MS with internal standardization, isobaric ion overlap correction, and standard addition methods. Sci Rep Fukushima Univ 56: 1-12

KIRWIN DJ (2005) Unidirectional solidification textures associated with intrusion related Mongolian mineral deposits. In: Seltmann R, Gerel O, Kirwin DJ (eds) Geodynamics and Metallogeny of Mongolia with Emphasis on Copper and Gold Deposits. CERCAMS, London, pp 63-85

Kormilitsyn VS, ManuYlova MM (1957) Rhytmic banded quartz porphyry. Bugdava Mountain, southwest Transbaykal region. Transact Mineral Soc, $2^{\text {nd }}$ Series, Part 86: 355-364 (in Russian)

Kostitsyn YA (2001) Sources of rare metals in peraluminous granites: a review of geochemical and isotopic data. Geochem Int 39: 43-59

Koval PV (1998) Regional Geochemical Analysis of Granitoids. Siberian Branch of Russian Academy of Sciences Novosibirsk, pp 1-491 (in Russian)

Kovalenko VI (1977) Petrology and Geochemistry of Rare Metal Granitoids. Nauka, Novosibirsk, pp 1-206 (in Russian)

KovALENKO VI (1978) The genesis of rare-metal granitoids and related ore deposits: In: ŠTEMPROK M (ed) Metallization Associated with Acid Magmatism vol. 3. Czech Geological Survey, Prague, pp 235-248

Kovalenko VI, Kovalenko NI (1976) Ongonites (TopazBearing Quartz Keratophyres): Subvolcanic Analogues of Rare-Metal Lithium-Fluorine Granites. Nauka, Moscow, pp 1-127 (in Russian)
Kovalenko VI, Kuzmin, Mi, Zonenshain LP, Nagibina MS, Pavlenko AS, Vladykin NV, Tseden Ts, GundsambuU TS, GoreglyAd AV (1971) Rare-metal granitoids in Mongolia: petrology, distribution of rare elements. Transactions 5: 1-239 (in Russian)

Kovalenko VI, Yarmolyuk VV, Bogatikov OA (1995) Magmatism, Geodynamics, and Metallogeny of Central Asia. MIKO - Commercial Herald Publisher, Moscow, pp 1-274

Kovalenko VI, Kostitsyn YA, Yarmolyuk VV, Budnikov SV, Kovach VP, Kotov AB, SAL'Nikova EB, Antipin VS (1999) Magma sources and the isotopic ( $\mathrm{Sr}$ and $\mathrm{Nd}$ ) evolution of Li-F rare-metal granites. Petrology 7: 383-409

Kovalenko VI, Yarmolyuk VV, Kovach VP, Kotov AB, KozAKOv IK, SAL'NIKOva EB, LARIN AM (2004) Isotopic provinces, mechanism of generation and sources of the continental crust in the Central Asian mobile belt: geological and isotopic evidence. J Asian Earth Sci 23: 605-627

Kramers JR, Tolstikhin IN (1997) Two terrestrial lead isotope paradoxes, forward transport modelling, core formation and the history of the continental crust. Chem Geol 139: 75-110

Krogh T (1973) A low contamination method for hydrothermal decomposition of zircon and extraction of $U$ and $\mathrm{Pb}$ for isotope age determinations. Geochim Cosmochim Acta 37: 485-494

Li S, WANG T, Wilde SA, Tong Y (2013) Evolution, source and tectonic significance of Early Mesozoic granitoid magmatism in the Central Asian Orogenic Belt (central segment). Earth-Sci Rev 126: 206-234

LINNEN RL, CUNEY M (2005) Granite-related rare-element deposits and experimental constraints on $\mathrm{Ta}-\mathrm{Nb}-\mathrm{W}-$ $\mathrm{Sn}-\mathrm{Zr}$-Hf mineralization. In: LiNNEN RL, SAMSON IM (eds) Rare-Element Geochemistry and Mineral Deposits. Geological Association of Canada Short Course Notes 17: pp 45-68

Loiselle MC, Wones DS (1979) Characteristics and origin of anorogenic granites. Geological Society of America, Abstracts with Programs 11: 468

MAKRYGINA VA (1981) Geochemistry of Regional Metamorphism and Ultrametamorphism of Moderate and Low Pressure. Nauka, Novosibirsk, pp 1-200 (in Russian)

McDonough WF, Sun S-s (1995) The composition of the Earth. Chem Geol 120: 223-254

ODGEREL D, ANTIPIN VS (2009) Avdar-Khoshutula intrusivedyke series of calc-alkaline, alkaline and rare metal granitoids of Central Mongolia. Izvestiya of Siberian Department of Russian Academy of Natural Sciences. Geology, Prospect and Survey of Ore Deposits 1(34): 58-68 (in Russian)

Pin C, Zalduegui JFS (1997) Sequential separation of light rare-earth elements, thorium and uranium by miniaturized extraction chromatography: application to isotopic analyses of silicate rocks. Anal Chem Acta 339: 79-89 
Pin C, Danielle B, Bassin C, Poitrasson F (1994) Concomitant separation of strontium and samarium-neodymium for isotopic analysis in silicate samples, based on specific extraction chromatography. Anal Chem Acta 299: 209-217

Povilaitis MM (1961) About rhythmic zonality of some granitic bodies. Izv Akad Nauk SSSR, Ser Geol 2: 35-50 (in Russian)

Raimbault L, Cuney M, Azencott C, Duthou JL, Joron JL (1995) Geochemical evidence for a multistage magmatic genesis of $\mathrm{Ta}-\mathrm{Sn}-\mathrm{Li}$ mineralization in the granite at Beauvoir, French Massif Central. Econ Geol 90: 548-576

Reyf F, SEltMAnn R, Zaraisky G, FedKin A (1999) Inclusion derived data on features of tantalite-saturated melt and its responsibility for the formation of the Orlovka tantalum deposit, Transbaikalia. Terra Nostra 99/6: 250-252

Rudge JF, Reynolds BC, Bourdon B (2009) The double spike toolbox. Chem Geol 265: 420-431

RudNick RL, GAO S (2003) Composition of the Continental Crust. In: Holland H.D, Turekian KK (eds) Treatise on Geochemistry vol. 3, The Crust. Elsevier-Pergamon, Oxford, pp 1-64

Shannon JR, Walker BM, Carten RB, Geraghty EP (1982) Unidirectional solidification textures and their significance in determining relative ages of intrusions at the Henderson Mine, Colorado. Geology 10: 293-297

SHAND SJ (1943) The Eruptive Rocks, $2^{\text {nd }}$ edn. John Wiley, New York, pp 1-444

Sun SS, McDonough WF (1989) Chemical and isotopic systematics of oceanic basalts: implications for mantle composition and processes. In: SAUNDERS AD, Norry MJ (eds) Magmatism in the Ocean Basins. Geological Society of London Special Publications 42: pp 313-345

StACEY JS, KRAMERS JD (1975) Approximation of terrestrial lead isotope evolution by a two-stage model. Earth Planet Sci Lett 26: 207-221

ŞEngör AMC, NATAL'In BA, Burtman VS (1993) Evolution of Altaid tectonic collage and Paleozoic crustal growth in Eurasia. Nature 364: 299-307

ŠTEMPROK M (1991) Ongonite from Ongon Khairkhan, Mongolia. Mineral Petrol 43: 255-273

Štemprok M, Seltmann R (1994) The metallogeny of the Erzgebirge (Krušné Hory). In: Seltmann R, KämpF H, MÖller P (eds) Metallogeny of Collisional Orogens. Czech Geological Survey, Prague, pp 61-69

TAUSON LV (1977) The geochemical types of granitoids and their potential ore capacity. Nauka, Moscow, pp 1-280 (in Russian)
TAYLOR RP (1992) Petrological and geochemical characteristics of the Pleasant Ridge zinnwaldite-topaz granite, southern New Brunswick and comparisons with other topaz-bearing felsic rocks. Canad Mineral 30: 895-921

Tischendorf G, Palchen W (1985) Zur klassifikation von Granitoiden. Z Geol Wiss 13: 615-627

Tuttle OF, Bowen NL (1985) Origin of granite in the light of experimental studies in the system $\mathrm{NaAlSi}_{3} \mathrm{O}_{8}$ $\mathrm{KAlSi}_{3} \mathrm{O}_{8}-\mathrm{SiO}_{2}-\mathrm{H}_{2} \mathrm{O}$. Geological Society of America, Memoirs 74, pp 1-153

Ushakov VI, Boguslavsky IS (1969) Geological position, structure and composition of the albitites of BuuralKhangai Massif (Central Mongolia) Notes of NIIGA. Regional Geology 14: 71-74 (in Russian)

VAsil'Eva IE, Shabanova EV (2012) Arc Atomic-Emission Analysis in Geochemical Research. In: Inorganic Materials. English translation of selected articles from Zavodskaya Laboratoriya. Diagnostika Materialov 78: pp14-24

WATSON EB, HARRISON TM (1983) Zircon saturation revisited: temperature and composition effects in a variety of crustal magma types. Earth Planet Sci Lett 64: 295-304

Whalen JB, Currie KL, Chappell BW (1987) A-type granites: geochemical characteristics, discrimination and petrogenesis. Contrib Mineral Petrol 95: 407-419

Windley BF, Alexeiev D, Xiao W, Kröner A, Badarch G (2007) Tectonic models for accretion of the Central Asian Orogenic Belt. J Geol Soc, London 164: 31-47

Wones DR, Eugster HP (1965) Stability of biotite: experiment, theory and application. Amer Miner 50: 1228-1271

Yarmolyuk VV, Kovalenko VI (2003) Batholiths and geodynamics of batholith formation in the Central Asian Fold Belt. Rus Geol Geoph 40: 1305-1320 (in Russian)

Yarmolyuk VV, Kovalenko VI, SAL'nikova EB, Budnikov SV, Kovach VP, Kotov AB, Ponomarchuk VA (2002) Tectono-magmatic zoning, magma sources, and geodynamics of the Early Mesozoic Mongolo-Transbaikalian magmatic area. Geotectonics 36: 293-311

Yarmolyuk VV, Kuzmin MI, Kozlovsky AM (2013) Late Paleozoic-Early Mesozoic within-plate magmatism in north Asia: traps, rifts, giant batholiths, and the geodynamics of their origin. Petrology 21: 101-126

Yarmolyuk VV, KuZmin MI, ERnSt RE (2014) Intraplate geodynamics and magmatism in the evolution of the Central Asian Orogenic Belt. J Asian Earth Sci 93: 158-179

Zonenshain LP, KuZMin MI, NATAPOv LM (1990) Tectonics of Lithosphere Plates of the Territory of USSR, Vol. 2. Nedra, Moscow, pp 1-334 (in Russian) 
